\title{
Insights into the crustal architecture from the analysis of gravity and magnetic data across Salem-Attur Shear Zone (SASZ), South- ern Granulite Terrane (SGT), India: an evidence of accretional tectonics
}

\author{
${ }^{1}$ Geological Survey of India, J L Nehru Road, Kolkata-700016, India \\ ${ }^{2}$ Indian Institute of Technology (Indian School of Mines), Dhanbad-826004, India; *Corresponding author, E-mail: sanjitism@gmail.com, \\ sanjitismagp@iitism.ac.in \\ ${ }^{3}$ Geological Survey of India, Hyderabad-500068, India
}

(Received: May 6, 2020; Revised accepted: December 30, 2020)

https://doi.org/10.18814/epiiugs/2020/020095

The gravity and magnetic surveys were carried out across E-W trending Salem-Attur Shear Zone (SASZ), Southern Granulite Terrane (SGT), India. The study envisages detail crustal architecture/ fabric across the SASZ from the analysis of potential field data. The Bouguer gravity map shows a circular gravity high closure over ultramafics complex of Chalk hill. Gravity model indicates that the complex is a spherical plug type body with depth extension of $\sim 7-8 \mathrm{~km}$. The SASZ is reflected by dominantly $E-W$ trending elongated isogals with low gravity values and depth extension of 3-4 km. The gravity high anomaly at the southeastern part of the SASZ indicates a high-density crustal unit that might have accreted along the southern margin of the shear zone. The magnetic map shows a high anomaly zone in the north-western block of the study area and bordered by a predominantly low anomaly zone at the southeastern boundary. The gravity-magnetic joint modelling reveals that a plane in south of the SASZ separates two upper crustal unit of contrasting density and susceptibility. The study indicates evidence of accretional tectonic in the southern margin of Dharwar Craton (DC) through arc magmatism. The SASZ has a shallow vertical extension ( $4 \mathrm{~km})$ and is characterized by diamagnetic rock.

\section{Introduction}

The Southern Granulite Terrane (SGT) provides a critical window to understand the tectonic evolution of Precambrian crust as it preserves the geological records of continent reconstruction, subductioncollision and terrane accretion (Sato et al., 2011; Praveen et al., 2014; Samuel et al., 2014; Santosh et al., 2015; Ratheesh-Kumar et al., 2016; Santosh and Li, 2018; Santosh, 2020). The SGT consists, collage of
Neoarchean to Neoproterozoic terranes/ tectonic blocks, which are characterized by distinct lithological assemblages, grades of metamorphism and isotopic age (Behera et al., 2019). The Meso to Neoarchean terrane adjacent to Dharwar Craton is termed as Northern Granulite Block (NGB; Clark et al., 2009; Brandt et al., 2014; Collins et al., 2014; Ratheesh-Kumar et al., 2016, Li et al., 2018, Chetty, 2017; Kumar et al., 2020a), which is made up of orthogneisses, metasedimentary rocks and charnockities. The NGB includes several crustal blocks (Fig. 1) such as Coorg Block (CB), Nilgiri Block (NB), Biligiri Rangan Block (BRB), Shevaroy Block (SB) and Madras Block (MdB). The present study area includes Shevaroy Block (SB), and Namakkal Block $(\mathrm{NkB})$ traversed by the Salem-Attur Shear Zone (SASZ; Fig. 1). The lithological assemblages of the study area formed between 3.2 to $2.6 \mathrm{Ga}$ (Behera et al., 2019). Some studies indicate the SASZ, as the northern frontier of the suture zone named as Palghat Cauvery Shear System (PCSS; Bhaskar Rao et al., 2003; Collins et al., 2007; Clark et al., 2009; Santosh et al., 2009, 2012). However, Behera et al. (2019), opined that the SASZ might not be a suture, but represent intra-terrane shear zone within a single Archean-Paleoproterozoic SGT. The geophysical signatures addressing crustal architecture in this important tectonic line is little known.

The Salem-Attur Shear Zone forms the north-eastern boundary of the PCSS or Cauvery Shear Zone (CSZ), which is a suture zone and separates NGB in the north and Madurai Block (MB) in the south (Chetty et al., 2003; Santosh et al., 2012; Collins et al., 2014). The MB (Fig. 1) occurs immediately south of the PCSS that extends up to Achankovil Shear Zone (ASZ) and includes Archean to Neoproterozoic charnockite-granite association along with gneiss, calc-granulite and quartzite (Bhattacharya et al., 2014). In the south of the ASZ, the Trivandrum Block (TB) occurs, which comprises dominantly of metasedimentary gneisses of Paleoproterozoic age and Neoproterozoic granitoids and syenites (Collins et al., 2014).

The geophysical studies, especially gravity and magnetic studies have immensely facilitated in understanding imprints of the ancient 
tectonics (Gibb et al., 1983; Mishra and Kumar, 2005; Williams et al., 2006; Kumar et al., 2009). The geophysical methods have important advantage of providing continuity of information if not available in post tectonic cover (Williams et al., 2006). Distinct gravity signatures (paired negative and positive gravity anomalies) are observed over the cratonic convergence and sutures at Precambrian age in Canadian Shield (Gibb and Thomas, 1976; Gibb et al., 1983). The geophysical studies in SGT have provided some key insights into crustal architecture and tectonics. Based on the signatures observed in gravity-magnetic anomalies, Proterozoic collisional tectonics across the PCSS/CSZ was

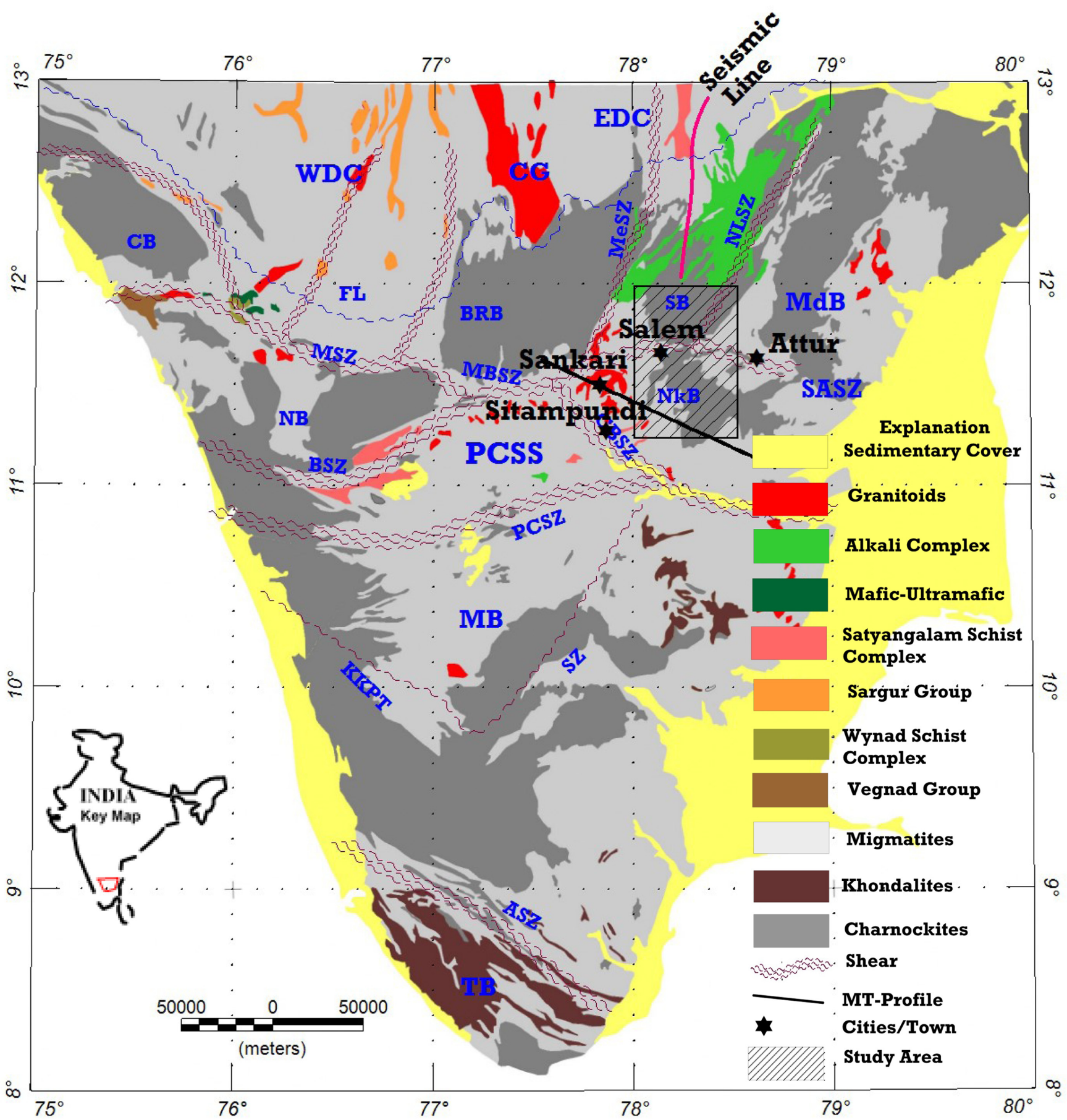

Figure 1. Generalized geological map of Southern Granulite Terrane (SGT) highlighting the study area. WDC: Western Dharwar Craton; EDC: Eastern Dharwar Craton; FL: Fermor Line (Transition Zone); CB: Coorg Block; NB-Nilgiri Block; BRB: Billigiri Rangan Block; SB: Shevaroy Block; MdB: Madras Block; NkB: Namakkal Block; MB:Madurai block; TB: Trivundram Block; CC: Closepet Granite; MSZ: Moyar Shear Zone; BSZ: Bhavani Shear Zone; MBSZ: Moyar-Bhavani Shear Zone; CBSZ: Cauvery-Bhavani Shear Zone; MeSZ: Mettur Shear Zone; PCSZ: Palghat-Cauvery Shear Zone; ASZ: Achankovil Shear Zone; KKPTSZ: Karur Kambam Painavu Trichur Shear Zone (Map compiled after GSI, 1998; Naganjaneyulu and Harinarayana, 2003; Reddy, 2003; Ghosh et al., 2004; Rao and Prasad, 2006; Yellapa et al., 2014; Samuel et al., 2014; Plavsa et al., 2015). MT-Profile modified from Naganjaneyulu and Harinarayana (2003). 
inferred by Mishra and Kumar (2005). Another study by Singh et al. (2006) inferred a faulted contact between SGT and Eastern Dharwar Craton (EDC), also mantle upwarp beneath the PCSS. This study also indicated a possibility of Himalayan type geodynamic event for evolution of SGT (Singh et al., 2006). The gravity study reveals, no difference in crustal density across the ASZ (Kumar et al., 2009). The magnetotelluric (MT) and seismic signatures are interpreted in terms continent-continent collisional tectonics along the Moyar-Bhavani Shear Zone (MBSZ; Fig. 1; Reddy et al., 2003; Rao et al., 2006; Nagajeneyulu and Harinarayana, 2003; Patro et al., 2014). A recent study indicates that the Nallamalai Shear Zone (NLSZ; Fig. 1), in the northeastern part of SGT, separating two blocks (Shevaroy Block \& MdB), is an oceanic suture, which preserves the antiquity of paleo-ocean, ocean-basin cessation ( $\mathrm{Li}$ et al., 2018).

Most of the geophysical studies mentioned above are based on the large-scale data, which lacks the analysis of high-resolution data set to address the crustal architecture of individual blocks and intervening structural or orogenic belts (Santosh, 2020). The geophysical signatures of the SASZ can provide an estimate of spatial and vertical subsurface geometry. Again the contrast of geophysical signatures across the SASZ is not available, which can enable to infer about the structure and paleo-tectonics of the study area. In the present study, we have acquired high-density gravity-magnetic data. It leads to high-resolution potential field maps followed by detail analysis of their derivative maps (Vaish and Pal, 2015; Kumar et al., 2019; Ganguli et al., 2019, 2020a,b) and joint gravity-magnetic modelling to address the critical issues. The collected rock samples provide information about density and susceptibly values which facilitate for understanding and the correlation of gravity-magnetic signatures.

The present study brings out detail gravity and magnetic signatures of the SASZ, its geometry, depth persistence, shallow and deeper crustal architecture and tectonics across SASZ. Our results reveal the presence of a high density mafic crustal unit at the southern margin of the SASZ. The study also reveals spatial as well as vertical extensions of the Salem mafic-ultramafic complex, popularly known as Chalk hill, which is reported to be Alaskan-type complex developed in rift-related setting (Yellappa et al., 2019; He et al., 2015). The present study is leading to propose an accretionary tectonic model across the SASZ.

\section{Regional Geological Setting}

The Archean Dharwar Craton (DC) borders the SGT in north, which is predominantly represented by a granite-greenstone terrane (Fig. 1). The SGT is a collage of tectonic units/blocks, each of which is characterized by distinct protolith, lithological assemblage and isotopic age. The tectonic units/blocks are dissected by crustal-scale shear/suture zones (Santosh et al., 2009; Collins et al., 2014; Behera et al., 2019). From north to south, the tectonic units/blocks are (i) Northern Granulite Block (NGB), (ii) Palghat Cauvery Shear System (PCSS), (iii) the Madurai Block, and (iv) The Trivandrum Block.

The NGB consists of orthogneisses, charnockities, mafic granulites and high-grade metasedimentary rocks; which represents deep exposure of either Mesoarchean crust or Neoarchean arc terrane (Brandt et al., 2014). Elevated lands are generally occupied by large charnockitic massif. The NGB is made up of Coorg Block, Biligiri Rangan Block
(BRB), Shevaroy Block (SB) and Madras Block (MdB); which was metamorphosed to granulite facies in late Archean to early Proterozoic (Collins et al., 2014). The Coorg Block, the oldest block of the SGT (Fig. 1, Santosh, 2020), at the western fringe of NGB is reported to be an exotic (Santosh et al., 2015) micro-continent; which comprises charnockities, gneisses and granitoids ( $>3.3-3.1 \mathrm{Ga}$ ). The Mettur Shear Zone (MeSZ) separates the BRB in the west and Shevaroy Block (SB) in the east. Two stages of the magmatic event (3.3-3.1 Ga \& 2.5 Ga) are recorded in BRB; which is dominantly made of charnockities, gneisses and granitoids (Ratheesh-Kumar et al., 2016). The SB block consists of charnockites and gneisses; which recorded magma emplacement at 2.76-2.53 Ga (Glorie et al., 2014; Clark et al., 2009). The Nallamalai Shear Zone (NLSZ) separates the Madras Block (MdB) from the SB. The MdB consists of charnockite, migmatite, granite, gneiss, charnockite and granodiorite; shows emplacement during 2.58-2.53 Ga (Li et al., 2018). The Nilgiri Block (Fig. 1) is a discrete tectonic block that evolved through Neoarchean arc magmatism in a convergent margin setting (Samuel et al., 2014). The SASZ, which separates the Shevaroy Block (SB) and Namakkal Block (NkB, Li et al., 2018), is interpreted as strike-slip shear zone (Drury and Holt, 1980; Chetty et al., 2003) with basal decollement and along which PCSS is thrusted over NGB (Biswal et al., 2010, Behera et al., 2019). The NkB is bordered by the SASZ at the north, the Cauvery-Bhavani Shear Zone (CBSZ) at the west and the Palghat Cauvery Shear Zone (PCSZ), at the south (Fig. 1). The NkB is dominantly comprised of charnockities, gneisses and intruded by ultramafic, ultrabasic, granites of Neoarchean to Neoproterozoic ages (Behera et al., 2019).

The PCSS is an east-west trending $70 \times 400 \mathrm{~km}^{2}$ major tectonic unit characterized by an anastomosing network of shear zones (Brandt et al., 2014; Chetty et al., 2017), which is bounded by Paleoproterozoic Moyar-Bhavani Shear Zone (MBSZ) and its eastward extension the SASZ, in north and Neoproterozoic PCSZ in south. The lithological assemblage consists charnockitic gneisses associated with biotite, hornblende-bearing migmatitic gneisses, which was intruded by ultramafic, ultrabasic and granite rocks of Neoarchean to Neoproterozoic ages. The north-western segment of the PCSS represents a discrete Meso to Neoarchaean "oceanic domain; while the southern part, the PCSZ, is either Neoproterozoic suture or a zone of late-Neoproterozoic reworking of older Madurai block (MB) basement (Brandt et al., 2014).

The Madurai Block (MB) occurs immediate south of the PCSS, which is the largest crustal block of southern India. The MB block is divided into two sub-blocks (Neoarchean Western sub-block and MesoNeoproterozoic eastern sub-block). It dominantly comprises of charnockite massifs intercalated with tonalitic/granodioritic gneisses, elongate narrow belts and slivers of metasedimentary rocks including quartzites, metamorphosed carbonates, iron formations and pelites (Behera et al., 2019; Santosh et al., 2009).

The southern boundary of the MB is marked by the Achankovil Shear Zone (ACSZ), which juxtaposed the MB with the Trivandrum Block (TB). The ACSZ is a well-defined lithological and isotropic boundary with prominent magnetic signature (Harris et al., 1996; Bartlett et al., 1998). The TB comprises dominantly of metasedimentary gneisses and khondolites. The subordinate lithologies include charnockities, calc-silicate rocks and pyroxene granulites (Santosh et al., 2009). In summary, the northern part of SGT preserves the Mesoarchean imprints. Towards the central part, the basement is prominently of 
Neoarchean to Paleoproterozoic age; while at the southern part, Paleoproterozoic rocks dominate (Santosh, 2020).

The SGT is mainly covered by ground gravity-magnetic, aeromagnetic, seismic and magneto-telluric (MT) surveys (Reddy et al., 2003; Nagajeneyulu and Harinarayana, 2003; Harinarayana et al., 2003, Mishra and Kumar, 2005; Mishra, 2011; Singh et al., 2006; Rao et al., 2006; Kumar et al., 2009; Patro et al., 2014). Based on the aeromagnetic and gravity signatures in conjunction with geochronological data, Mishra and Kumar (2005) inferred two stages of compressive regimes during Neoarchean and late Proterozoic in the PCSS. The analysis of gravity gradient data shows the absence of first-order gravity maxima along the PCSZ; which suggests the PCSZ to be an intra-cratonic litho-tectonic feature (Kumar et al., 2009). The electrical structure derived from MT survey suggests that the SGT is characterized by high-resistivity upper crustal column overlying less-resistive lower crustal column (Patro et al., 2014). The model further reveals the presence of three subsurface

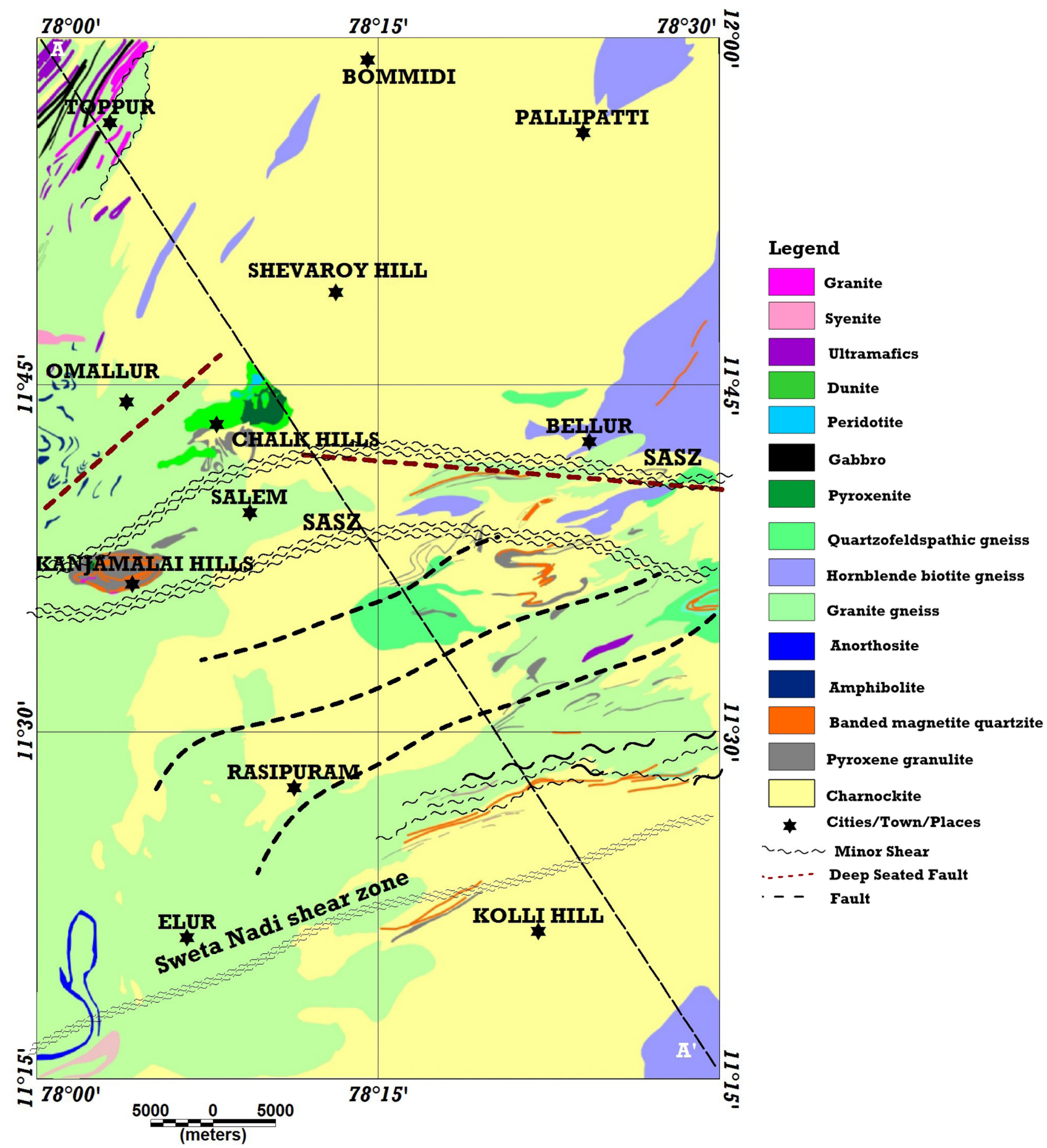

Figure 2. Geological map of the study area. (Source: Geo Data Division, Geological Survey of India, Southern Region, Hyderabad); A-A' profile selected to study the gravity and magnetic response over geology and for gravity-magnetic modelling. Brown dashed lines are deep seated fault (modified from Grady, 1971). The Salem-Attur Shear Zone (SASZ), Sweta-Nadi Shear Zone and faults (black dashed line) are modified from Behera et al. (2019). 
conductive feature reaching up to upper mantle depths beneath the PCSS. The MT study (Naganjaneyulu and Harinarayana, 2003) across the study area (Fig. 1) reveals low resistivity values though out the upper crust in south-eastern part of the area over charnockities and comparatively higher resistivity values in north-western part of the study area over granite gneiss.

The seismic study across the PCSS shows a four-layer velocity structure with 6.1, 6.5, 6.0 and $7.1 \mathrm{~km} / \mathrm{s}$ with prominent Moho up-warp beneath the PCSZ (Reddy et al., 2003). The seismic tomography study indicates average crustal thickness for SGT is $36 \mathrm{~km}$ and seismic velocity is $6.4 \mathrm{~km} / \mathrm{s}$ (Rai et al., 1993). The study from flexure inversion analysis reveals (Ratheesh-Kumar et al., 2016) that the NB has an average crustal thickness of $\sim 41 \mathrm{~km}$, the BRB has an average crustal thickness of $38 \mathrm{~km}$; while the PCSZ is marked by a distinct zone of a lower crustal thickness $(\sim 32 \mathrm{~km})$. The variation in crustal thickness is not evident across the SASZ and derived thickness from flexure inversion analysis is $\sim 33 \mathrm{~km}$ (Ratheesh-Kumar et al., 2016). The isostatic study indicates that crustal thickness around the SASZ is $\sim 35-36 \mathrm{~km}$ (Kumar et al., 2009). The seismic study in northern part of the SASZ (near Bomidi, Fig. 2) indicates a four-layer velocity section with Moho depth of $\sim 42 \mathrm{~km}$.

The density values of the rock samples in the western part of SGT across Bavali Shear Zone were reported earlier (Radhakrishna et al., 2003), but the density and susceptibility values of the rock samples from the study area is not yet reported. In fact, susceptibility values of the rock samples from SGT in published literature are very few.

\section{Geological Set Up of Study Area}

Physiographically, the study area (Fig. 1) represents an undulating terrain encompassing Shevory hill (1630 m, maximum elevation), Kolli hill (1415 m, maximum elevation) and other hillocks like Chalk hill, Kanjamali hill. Geologically (Fig. 2), the area is covered by rocks of the age group from Archaean to Neoproterozoic. The Charnockite group of rocks and Peninsular Gneissic Complex (PGC) are two prominent geological units in order of abundance. The Charnockite Group consists of charnockite, banded magnetite quartzite (BMQ), amphibolites, and pyroxene granulites. While, Peninsular Gneissic Complex (PGC) consists of hornblende biotite gneiss, hornblende gneiss, and biotite gneiss (GSI, 1995). The mafic-ultramafic complex near Salem (Fig. 2), in Shevaroy Block, which outcrops as semi-circular to elongated body, is formed by altered ultramafic rocks like dunites, peridotites, pyroxenites, gabbros, amphibolites and quartzo-feldspathic alkaline rocks of Neoproterozoic age (Yellapa et al., 2019). The complex is known as Chalk hill of Salem (Fig. 2), which is located $7 \mathrm{~km} \mathrm{NE}$ of Salem town on the Salem-Bangalore highway. The complex is compared with Alaskan-type complex and is well known for its magnesite potential (Yellapa et al., 2019). The shonkinites in the vicinity of the ultramafic complex reported with crystallization age of $\sim 820$ Ma and alkaline magmatism associated with it took place along an aborted rift (He et al., 2015). The Kanjamalai Mafic Complex (KMC) is another small but crucial geological unit. It is a mafic relic semi-circular elevated body comprising garnetiferrous mafic granulites and other high-grade gneisses interfolded with BMQs (Mohanty and Chetty, 2014). There are granites that occur extensively as broad intrusive at both the sides (north and south) of the hill. The reported age of this complex is late
Archean $(2500 \mathrm{Ma})$. The KMC is suggested to be dismembered from other mafic/ultramafic complexes of the NGB and originated from depleted mantle source at Neoarchaean in MORB setting (Noack et al., 2013). Existence of a possible detachment zone in the north-western part of the KMC separating contrasting litho-structural unit is also reported (Mohanty and Chetty, 2014). In the south-western part of the study area, an anorthosite band is exposed, which is a part of Sittampundi Anorthosite Complex (SAC). The Neoarchean SAC is located at $\sim 80 \mathrm{~km} \mathrm{SSW}$ of Salem town (Fig. 1 \& 2) which largely preserve the igneous stratigraphy. From the base to upward, the complex comprised of dunite, pyroxenite, anorthosite and meta-gabbro (Mohan et al., 2013). In the north-western part of the study area, small granitic bodies occur, which are part of the Sankaridurg granite (Chetty et al., 2016) emplaced between 0.6-0.4 Ga (Behera et al., 2019). A diverse sequence of mafic and ultramafic assemblages, gneiss, charnockite, pyroxene granulites, and banded magnetite quartzites are exposed along the SASZ. Majority of the rock types around the SASZ are highly deformed and converted into mylonites (Yellappa et al., 2019). The Sweta Nadi Shear zone, trending in ENE-WSW direction, which is running through the southern part of the study area, reported by Behera et al. (2019) but details are not available. The geophysical studies addressing the shallow crustal structure of Shevaroy Block, the SASZ or Nammakal Block (NB) is hardly available in public domain.

\section{Methodologies and Principle}

\section{Gravity Data Acquisition and Processing}

We have acquired high-resolution gravity and magnetic data along all the accessible roads available in 1:50,000 scale topographical map of the study area. A total of 1700 observations were performed in $4320 \mathrm{~km}^{2}$ area (Fig. 3). The station positions and elevations were determined using differential GPS (DGPS) instrument. Post-processing technique was applied to obtain the elevation of each station which resulted in mm level accuracy. Highly rugged hilly terrain and dense forest at places hindered station occupancy. CG-5 gravimeter and GSM-19 Proton Precession Magnetometer were deployed for simultaneous measurement of gravity and magnetic data along with station elevations through DGPS. All the gravity stations were tied with IGSN-1971 gravity base established at Salem, Tamil Nadu by Geological Survey of India (GSI). We had applied linear drift correction on gravity data on a daily basis. After applying Free-air correction, we have used the standard crustal density of $2670 \mathrm{~kg} \cdot \mathrm{m}^{-3}$ for Bouguer corrections. The latitude correction was performed using International gravity formula (1980). The terrain correction was necessitated due to the fact that the area covers two major hills and characterizes undulating landscape. The GEOSOFT software was used for terrain correction. The Shuttle Radar Topography Mission (SRTM) data (https://gdex. cr.usgs.gov/gdex/) was used to prepare regional elevation grid. Local elevation grid was prepared by merging the elevation of each gravity station with SRTM data. The corresponding values of terrain correction for each station were assigned to the measured gravity values (Mishra, 2011; Kumar et al., 2011). The corrected gravity data were gridded with a cell size of $1000 \mathrm{~m}$ using minimum curvature technique (Radice et al., 2017). 


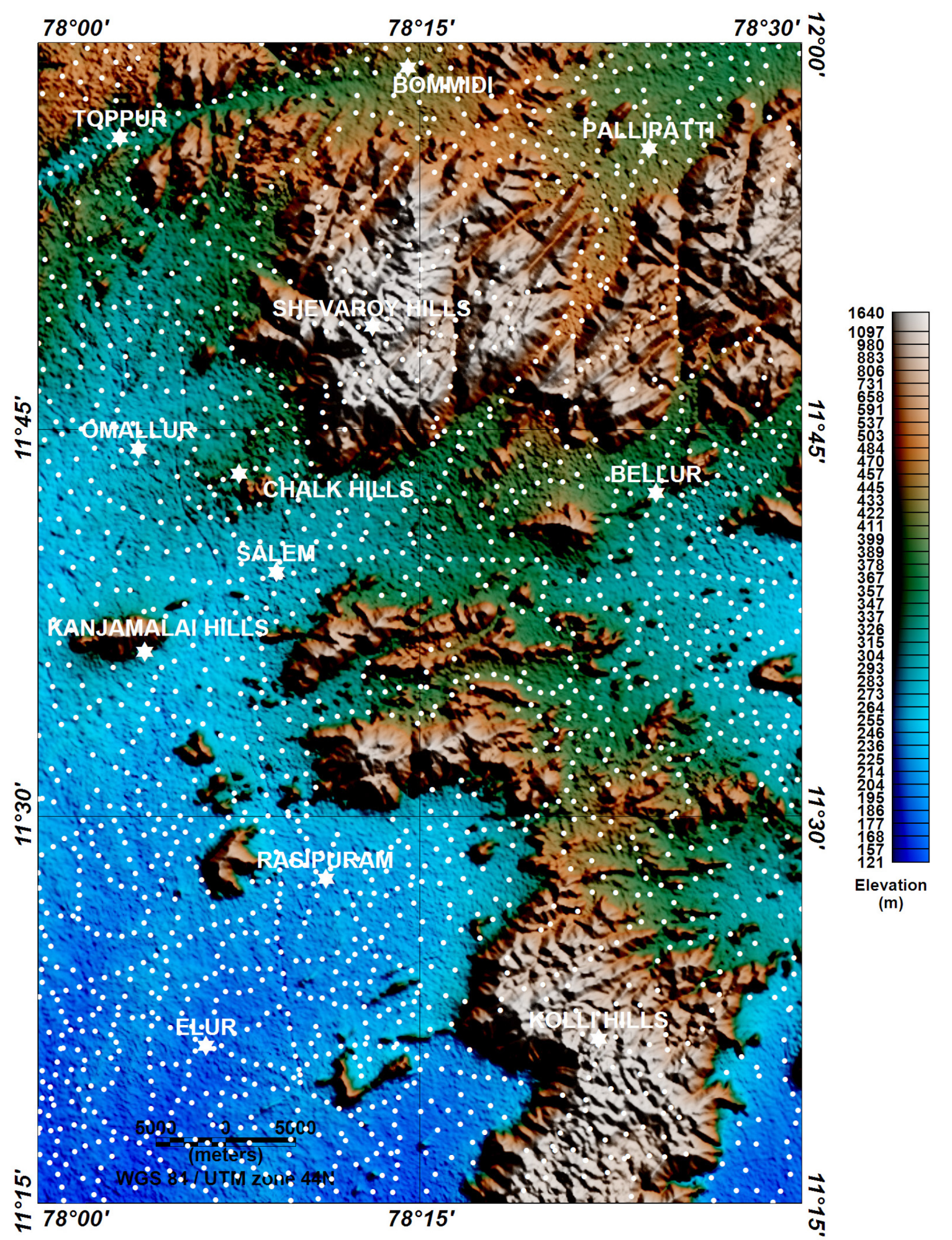

Figure 3. Gravity-magnetic stations overlaid on topographic map of the area. White dot represents gravity and magnetic stations.

\section{Power Spectrum Analysis of Gravity and Magnetic Data}

Generally, potential field (gravity \& magnetic) data represents the superposition of the anomalies of various frequencies associated from the sources at different depths. The power spectrum analysis of the gravity and magnetic data has been found very useful for assessing the approximate depth of the causative bodies (Spector and Grant, 1970; Blakely, 1996; Ganguli et al., 2020 a, b; Kumar et al., 2020b; Sahoo and $\mathrm{Pal}, 2020)$. The power spectrum of potential field data provides a correlation between finite depth sources of the bodies and finite range of wavelength using the relationship $P(w)=A \exp (-2|w| h)$, where $P(w)$ is 
the power spectrum, $A$ is the constant for randomly distributed source, $w$ is the wave-number; $h$ is the depth to the source (Ganguli et al., 2019).

The slope of the logarithm power spectrum as a function of wavenumber provides the depth to the of causative sources. The slope at smaller wave-numbers provides the depth of deeper source and subsequent slopes at higher frequency estimate the depth to the shallower sources.

\section{Residual and Regional Analysis of Gravity Data}

Residual of gravity data was carried out to analyze the gravity response of shallow causative sources. The wavenumber analysis was applied to extract the regional and residual component from Bouguer gravity (Spector and Grant, 1970; Mishra, 2011; Ganguli et al., 2020a,b).

The regional anomaly map brings out the deeper crustal fabrics. Upward continuation filter at a different height, i.e., $5 \mathrm{~km}, 10 \mathrm{~km}, 15 \mathrm{~km}$, and $20 \mathrm{~km}$ was applied to understand the depth persistence of various anomalies and deeper crustal fabrics. The resulting gravity field from an upward continuation level of ' $Z$ ' retains anomalies from sources below a depth of $Z_{0}=Z / 2$, whereas sources above are more attenuated (Jacobsen, 1987; Lyngsie et al., 2006).

\section{Horizontal Derivative of Gravity Data}

The horizontal derivative map of the potential filed data is useful in delineating the boundaries of abrupt lateral changes in density (Blakely et al.,1996; Pal et al., 2015, 2016; Narayan et al., 2017; Kumar et al., $2020 \mathrm{~b}, \mathrm{c})$. In the process, short-wavelength anomalies are enhanced, and the gradient is located directly over the edges of the density discontinuity. The horizontal gradient map is rather simple to interpret and requires no assumption about the source parameters (Pal and Majumdar, 2015; Sahoo and Pal, 2019; Chouhan et al., 2020a, b).

\section{Magnetic Data Acquisition and Processing}

The acquired ground magnetic data were corrected for diurnal effect and IGRF variation (2015 epoch). The magnetic data was gridded by applying minimum curvature algorithm with the grid cell size of $1000 \mathrm{~m}$. The amplitude and anomaly pattern of magnetic anomaly map or Total Intensity Magnetic (TMI) map is a function of i) susceptibilities of the rock units, ii) magnetic latitudes of their occurrence, and iii) the orientation of the elongated axis of the geological body with reference to the magnetic meridian. The magnetic response of a magnetic-body near the magnetic equator will appear quite different from magnetic signatures at middle latitudes or poles. Average magnetic inclination value for the study area is $9.8^{\circ}$; hence the survey area is near to the magnetic equator, and the geomagnetic field is mostly horizontal. In case of induced magnetization, a magnetic source close to the magnetic equator opposes the earth's geomagnetic field, and a negative (low) anomaly is observed (Dobrin and Savith, 1988; Mishra, 2011). To negate the complexities due to the bipolar nature of the anomaly, we have used Reduced to Equator (RTE) transformation operator. The RTE magnetic anomaly (MARTE) map is shown in Fig. 6. In general, for the present survey area, the lithounits with ferromagnetic mineral content (high susceptibility) will give a magnetic low, and lithounits with diamagnetic mineral content will provide a magnetic high (Ganguli et al., 2019, 2020a,b).

\section{Euler Deconvolution}

A comprehensive treatment of Euler Deconvolution (ED) is provided by Blakely (1996), Reid (1990), Reid \& Thruston (2014). The technique mainly responds to gradients in the potential field data. It effectively traces the edges and estimates depths of the causative sources without any prior information of the source magnetization or remanence (Kumar et al. 2018, 2019; Horo et al., 2020).

The Euler homogeneity equation can be expressed for the potential field as follows.

$$
\left(x-x_{0}\right) \frac{\partial T}{\partial x}+\left(y-y_{0}\right) \frac{\partial T}{\partial y}+\left(z-z_{0}\right) \frac{\partial T}{\partial z}=-N(B-T)
$$

Where $\left(x_{0}, y_{0}, z_{0}\right)$ are the coordinates of the source location; Total field $T$ is measured at the observation point $(x, y, z)$ and $B$ is the background field; $N$ indicates the structural index (SI) and relates to rate of change of potential field with distance (Reid et al., 1990), which characterizes source geometry. The source points resulting from solutions of ED are positioned at the border of density/susceptibility inhomogeneities.

The ED is solved within a grid of gradient values and field values. The SI varies from 0 to 3 . The window size (WS), structural index N, and depth tolerance (d) are three important parameters for estimating best source locations.

\section{Gravity-Magnetic Modelling}

The gravity-magnetic joint modelling was attempted along the profile A-A' (Figs. $2 \& 5$ ) as it cut across the majority of the significant gravity-magnetic anomalies and geological features. The strike length of the profile selected for modelling is $92 \mathrm{~km}$, and the maximum wavelength of the gravity anomalies is $\sim 25 \mathrm{~km}$. So we have considered $20 \mathrm{~km}$ vertical crustal section; because it appears that the causative sources of the anomalies are confined within $20 \mathrm{~km}$. In joint gravity-magnetic modelling, it is assumed that gravity-magnetic anomalies have the same source. The aim of simultaneous determination of density and magnetization distribution is to derive geologically realistic model and reduce the non-uniqueness of the model (Gessner et al., 2016; Singh et al., 2014; Tiwari et al., 2006). The gravity-magnetic joint model is initially constrained using available geophysical and petrophysical data (de Castro, 2011), to reduce the ambiguity and to produce a realistic geological section. The magnetic data is dominated by high-frequency anomalies than gravity data, so more emphasis was given on magnetic anomalies to arrive at shallow crustal configurations. Here, we have considered induced type magnetization as RTE map indicates mainly induced type magnetization. A north-south oriented seismic line (Fig. 1) which terminates at Bommidi (Fig. 2) shows a four-layer crustal section (Reddy, 2003). The initial crustal configuration is derived from the above mentioned seismic section. The upper crustal and mid-crustal velocity values are $6.15 \mathrm{~km} / \mathrm{s}$ and $6.55 \mathrm{~km} / \mathrm{s}$ with an interface at $\sim 12 \mathrm{~km}$. The density values of the crustal layer are determined using nonlinear velocity density regression analysis of Christensen and Mooney (1995). The density and susceptibility values of the shallow crustal rock units were assigned according to data collected in the present study on petrophysical parameter and outcrop geology. This was followed by forward modelling performed using GM-SYS, 2004 software in which 
interactively crustal model is adjusted, and corresponding real-time response of the combined gravity-magnetic data is observed. Different sources were introduced in the upper crust for better fitting between the observed and calculated magnetic anomalies (de Castro et al., 2014; Pilkington, 2006). After obtaining a satisfactory fit, the final results were derived by applying an optimization scheme within the logical limits of geology and tectonics. The calculations of gravity-magnetic model responses were adapted from Talwani et al. (1959), and Talwani and Heirtzler (1964). The optimization algorithm adopts a 2D flat earth model, which uses USGS SAKI implementation (Webring, 1985) of the Marquardt inversion algorithm (Marquardt, 1963) to linearize and invert the data sets. The density and magnetization can be inverted jointly or separately, keeping the other fixed, during the iteration process. The model geometries were kept fixed during the inversion process. The RMS errors between computed and observed data are approximately 1.2 and 19.285 for gravity and magnetic data, respectively. A relatively poor fit for magnetic data is expected as the magnetic field is characterized by the complex vectorial character in comparison to scaler behaviour of gravity field (Bauer et al., 2003; Ramadass et al., 2006; de Castro, 2014).

\section{Collection of Rock Samples}

During the gravity-magnetic survey, we collected a total of 280 rock samples from various demonstrative lithological units of the study area for density and susceptibility measurements (Table 1). However, few specimens of charnockites, banded magnetite quartzite, granite gneiss with skewed density and susceptibility values are omitted.

\section{Results}

\section{Density and Susceptibility of the Rock Samples}

The lithounits of the study area are of Archean to the Proterozoic age. The average density of the rock samples for the study area varies from
$2670-3250 \mathrm{~kg} \cdot \mathrm{m}^{-3}$. The density values for the rest of the lithounits are more than $2800 \mathrm{~kg} \cdot \mathrm{m}^{-3}$ except granite gneiss, and this is a typical signature of high-grade metamorphic terrain (Table 1). Charnockite is the most abundant lithological unit of the area with an average density of $2830 \mathrm{~kg} \cdot \mathrm{m}^{-3}$, but the susceptibility of the rock unit varies widely. The samples representing banded magnetite quartzite (BMQ) registered the highest density (an average density of $3.25 \mathrm{gm} / \mathrm{cc}$ ) and highest susceptibility values (0.0062-0.0078 CGS unit). The granite-gneiss exhibit lowest-density (an average density of $2670 \mathrm{~kg} \cdot \mathrm{m}^{-3}$ ) and lowest susceptibility values (0.000003-0.00055 CGS unit). The measured density values of dunites are on the lower side than the expected, probably because the exposed dunites are serpentinized.

Based on the measured physical properties (density and susceptibility) from the collected rock samples, a map showing the distribution of susceptibility and density was prepared for a corroborative understanding of the physical properties (Fig. 4). The susceptibility map shows moderate to high susceptibility zone encompassing Salem, Shevaroy hill, Pallipatti in NNE-SSW direction, but this zone is represented by low to moderate density rocks. At Kanjamalai hill high susceptibility zone is associated with high-density lithounits. At Kolli hill low to moderate susceptibility zone is associated with moderate to high-density lithounits. At the south-western part, high-density rocks occur with low susceptibility values. Geologically charnockite is the dominant lithounits in both Shevaroy and Kolli hills, but the charnockites of Shevaroy hill show moderately high susceptibility; whereas, for Kolli hill it shows low to moderate susceptibility values. It may be noted that the magnetic character of rock is determined by several factors; but most important are 1) the bulk geochemistry of the rock including the amount of $\mathrm{Fe}$ content with different oxidation state, and 2) thermal-heating history; which lead to variable susceptibility of the same rock type.

\section{Bouguer Gravity}

The Bouguer gravity anomaly primarily reflects subsurface density contrast and in turn, reveals subsurface geology and structure. The

Table 1. Density and susceptibility values of the representative rock samples of the study area. BMQ: Banded Magnetite Quartzite, HBG: Hornblende Biotite Gneiss, HG: Hornblende Gneiss

\begin{tabular}{cccccc}
\hline \hline \multirow{2}{*}{ Sl. No } & \multirow{2}{*}{ Rock types/mineral } & \multirow{2}{*}{ No. of samples } & \multicolumn{2}{c}{ Density, D, (gm/cc) } & \multicolumn{2}{c}{$\begin{array}{c}\text { Magnetic susceptibility (S) range } \\
\text { in CGS units }\left(\times 10^{-6}\right)\end{array}$} \\
\cline { 4 - 5 } 1 & Charnockite & 136 & $2.70-3.16$ & 2.83 & $10-2853$ \\
2 & BMQ & 04 & $3.02-3.51$ & 3.25 & $6200-7800$ \\
3 & Mafic Granulite & 50 & $2.75-3.39$ & 3.03 & $11-1908$ \\
4 & Meta Gabbro & 16 & $2.82-3.40$ & 3.07 & $15-1981$ \\
5 & Pyroxenite & 05 & $2.99-3.28$ & 3.16 & $53-218$ \\
6 & Gabbro & 03 & $2.1-3.17$ & 2.94 & 37 \\
7 & Dolerite & 03 & $3.00-3.10$ & 3.04 & $967-1771$ \\
8 & Granite Gneiss & 22 & $2.56-2.75$ & 2.67 & $3-550$ \\
9 & HBG & 12 & $2.68-3.12$ & 2.84 & $6-908$ \\
10 & HG & 07 & $2.65-2.93$ & 2.80 & $8-338$ \\
11 & Dunite & 02 & $2.73-3.07$ & - & $97-280$ \\
12 & Magnesite & 01 & 2.57 & - & $12-1190$ \\
13 & Ulitramafite & 06 & $2.91-3.25$ & 3.14 & $17-1311$ \\
14 & Amphibolite & 04 & $3.09-3.16$ & 3.12 & \\
\hline
\end{tabular}




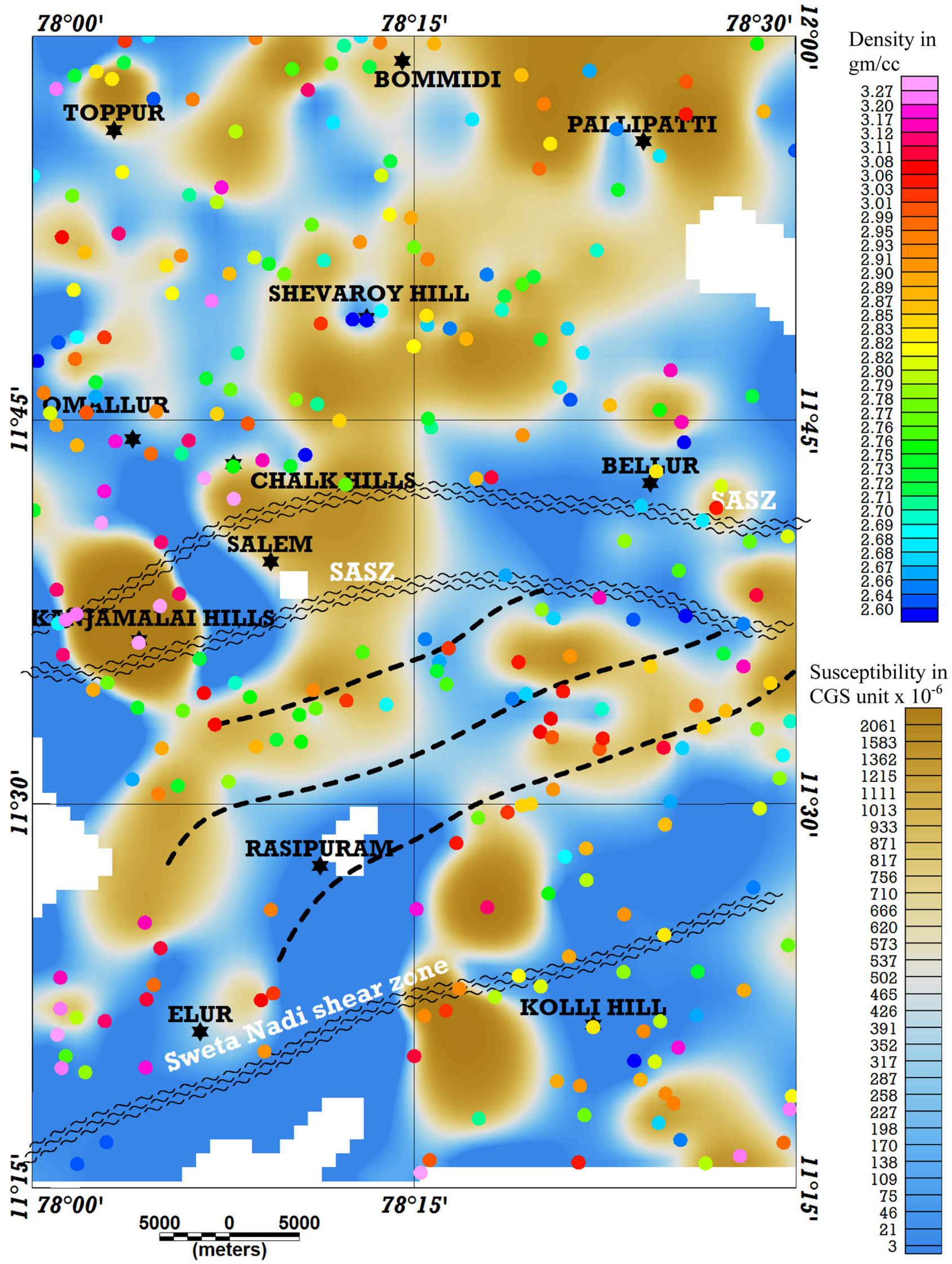

Figure 4. Circular dots indicate location of rock samples collected from the study area for understanding the variations of the density and susceptibility. Susceptibility image map is generated using susceptibility values of all the samples. Circular dots with different colours are used to indicate density variation at all the sample locations, which are overlaid on the susceptibility image map for combined representation. 


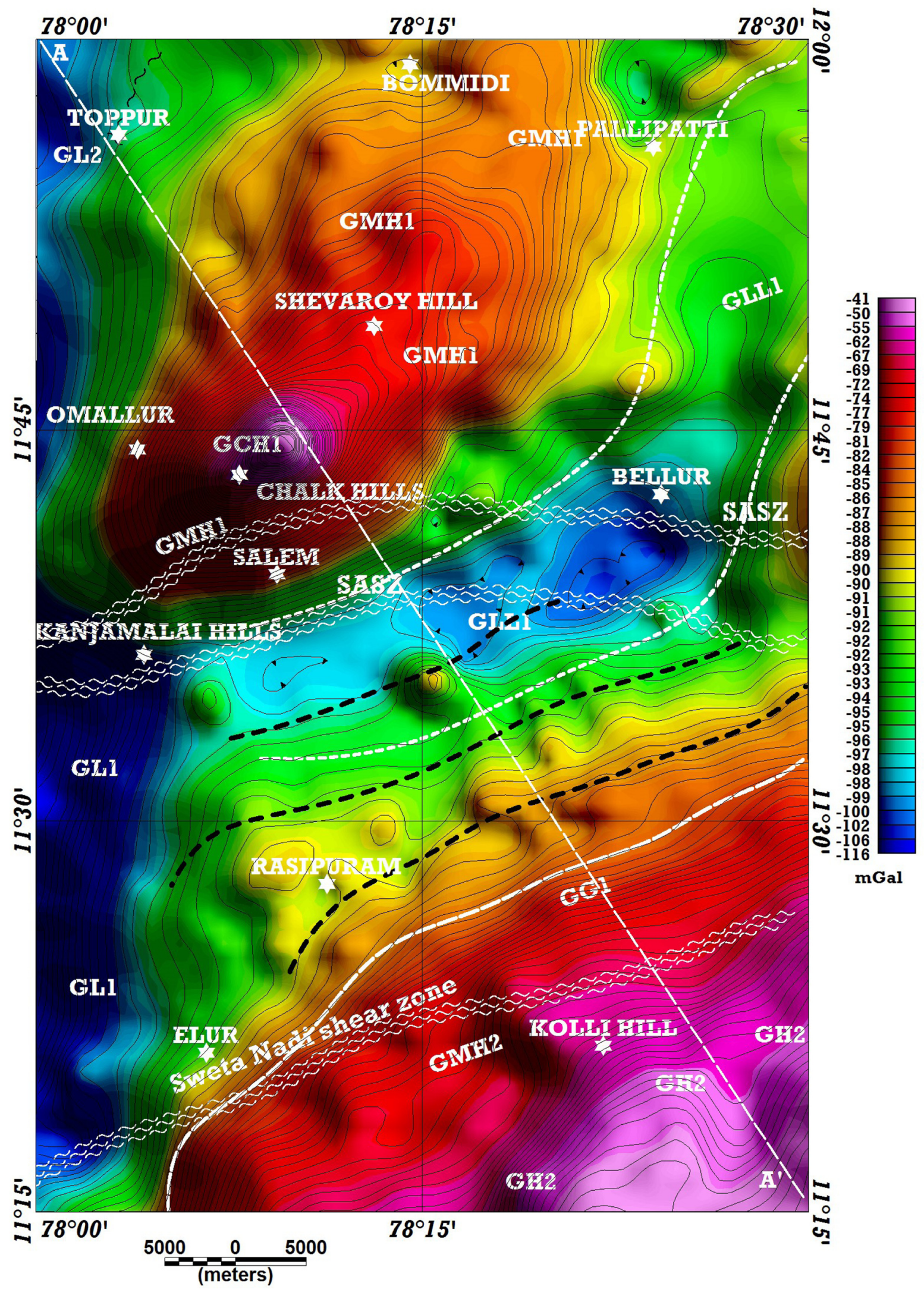

Figure 5. Bouguer Gravity map of the study area. The warm colour indicates gravity high zones and the lighter colour indicates gravity low zones. GH-2: gravity high zone; GMH1, GHM2: gravity moderate to high zone; GL1: gravity low; GLL1: gravity low linear; GCH1: gravity high closure; GG1: gravity gradient. $A-A^{\prime}$ profile selected to study the gravity and magnetic response over geology, and for gravity magnetic modelling. The SASZ and Sweta-Nadi shear zone are modified after Behera et al. (2019). The black dashed line indicates fault, which are modified after Behera et al. (2019). See the circular gravity high over Chalk hills, and NEE-SWW trending gravity liner low corresponding to the SASZ. 
gravity anomaly map (Fig. 5) shows an overall variation of $75 \mathrm{mGals}$ with the lowest value occurring in the south-western part of the study area (-116 mGals) and highest value happening near Chalk hill (-41 $\mathrm{mGals}$ ). Based on the gravity values and anomaly pattern, gravity map is classified into the high, moderately high and low anomaly zone.

The moderate-high gravity anomaly zone of broad elliptical shape marked as GMH1 (Fig. 5) is observed over the elevated land of the Shevaroy hill, which is represented by charnockite group of rocks. A circular gravity high (GCH1) surrounded by GMH1 at Chalk hill is the distinct anomaly pattern. It demarcates the boundary of the altered ultramafic unit, which is veined by secondary magnesite deposit. Anomaly pattern suggests a circular plug-like body which might have emplaced on the basement through weak planes developed due to shearing/rifting. It is further interesting to notice that GCH1 almost occurs at the junction of two deep-seated faults (Grady, 1971); however, those faults do not find signatures in isogals pattern.

A prominent linear gravity low to moderate (GLL1, Fig. 5) anomaly zone running in ENE-WSW direction suggests a high strain sheared zone which indicates sheared gneisses and may represent gravity expression of the Salem-Attur Shear Zone (SASZ). The GLL1 takes a northward swing from Bellur and has a width of $\sim 12-13 \mathrm{~km}$. However, the northern extension of the GLLI shows moderate gravity anomaly values which indicate less sheared rocks. There are pockets of some circular high-frequency closures within the GLL1, which are probably pre/ post-shearing emplacement of moderate to high-density rock units.

A low gravity anomaly (GL1, Fig. 5) with gravity value ranging from -100 to $-116 \mathrm{mGals}$ at the south-western part indicates the occurrence of a low-density granitic pluton as the plutons are generally associated with moderate to large (negative) gravity anomalies (Ranganai et al., 2019). The pluton is the extension of neighboring Sankaridurg granitoids (Chetty et al., 2016). The abrupt termination of NNE-SSW isogals associated with the GGL1 at the eastern part of the GL1 suggests that granitic emplacement was a post shearing event, probably related to $600 \mathrm{Ma}$ tectonic event (Ghosh et al., 2004). Another gravity low 'GL2' is the northward continuation of GL1 and indicates northward extension of the same granitic plutons. The depth extension of gravity plutons represented by gravity lows is greater than the depth extension of the shear zone as revealed by wavelengths and amplitude of the isogals.

The Kanjamali Mafic Complex (KMC), bears no significant signature in the gravity map (Fig. 5). Probably, the high-density mafic granulites have minimal depth extension, and gravity low caused by the occurrence of granitiods at both sides of the hill masked the signature of the mafic bodies. It may also indicate that the base of the KMC is occupied by granitoids. However, the isogal pattern across the KMC abruptly changes as NE-SW trending isogals suddenly changes to N-S trending isogals.

A linear increase of gravity values is observed across Kolli hill from NW to SE as represented by moderate to the steep gradient of gravity contours (GG1) at the southeastern part. The gravity contour trends in NEE-SSW direction and sensitive to the trend of GLL1. Some geologically demarcated fault also follows the same trend (Behera et al., 2019). The moderate to high gravity at the southeast region is marked as GMH2. Based on the difference of isogals pattern and values between GMH1 (Shevaroy hill) and GMH2 it is suggested that Kolli hill represents a distinct high-density crustal unit. The anomaly pat- tern and amplitude of gravity high GH2 at the southeast corner of the study area indicate the occurrence of a high-density body at the very shallow crustal level. Apart from above mentioned broad anomalies, few high-frequency anomaly patterns are representing shallow causative source in gravity map, will be discussed in the context of residual gravity anomaly map.

\section{Magnetic Anomaly}

The magnetic anomaly map shows several distinct moderately-high to high zones and moderately-low to low zones (Fig. 6). The northwestern part is represented by medium to high anomaly (MH-I) zone with NE-SW strike, which indicates the presence of para to the diamagnetic lithounit. The geological map shows that the area enclosed by the MH1 is represented by granite-gneiss. The most prominent moderate to high anomaly zone running in $\sim \mathrm{E}-\mathrm{W}$ direction is marked by MH-II. This zone follows the trend of SASZ. The MH-II is dotted by few high-frequency, low-magnetic anomalies suggesting the presence of mafic lithounits within gneisses. The $\mathrm{KMC}$ is manifested as a low-magnetic enclosure within MH-II. The petrological analysis of the rock sample from KMC shows that ortho and clinopyroxenes are the dominant minerals (Noack et al., 2013). It suggests that rock units comprising pyroxene minerals predominantly explain the low-magnetic anomaly in the study area. The ultramafic complex of Chalk hill is manifested as moderate to high amplitude anomaly. The chemical analysis of dunites from Chalk hill shows that $\mathrm{SiO}_{2}$ and $\mathrm{MgO}$ are dominant oxides (Yellappa et al., 2019). It suggests that high anomalies are the manifestation of rock with poor Fe content. The magnetic low zone ML-I is mainly attributed to charnockites. The high amplitude closures are indicative of the presence of mafic/ultramafic rocks within charnockites. The ML-II is similarly attributed to mafic charnockites. The zone represented by MH-III is the manifestation of exposed granite gneiss. A moderate to low anomaly ML-III is another prominent anomaly zone. The magnetic low 'ML-III' is caused by the presence of mafic to ultramafic unit as it corroborates well with GH2 (Fig. 5), though it may be concealed as the mafic/ultramafic rocks are not apparent in the geological map (Fig. 2). The other smaller magnetic high anomalies mostly represent silicic lithounit such as granite gneiss, and moderate anomalies represent hornblende biotite gneiss or hornblende gneiss. The smaller order magnetic lows are the manifestation of mafic units.

\section{Power Spectrum Analysis of Gravity and Magnetic Data}

The analysis of gravity power spectra indicates that $15 \mathrm{~km}$ and 2.0 $\mathrm{km}$ are the cut-off wavelengths (Fig. 7a), which can be used for separating deeper and shallower source, respectively. A Butterworth bandpass filter, using a passband wavelength of $15 \mathrm{~km}$ and $2.0 \mathrm{~km}$, has been applied to gravity data to eliminate the effect of large-scale deeper causative sources and near-surface noise. The power spectrum of gravity delineates three slope sections that indicate depths of the density interfaces at $8.0 \mathrm{~km}, 3.0 \mathrm{~km}$, and $1.0 \mathrm{~km}$ (Fig. 7a). The deepest interface probably represents the depth of the ultramafic complex at Chalk hill. The second density interface may be indicating depth extension of the mylonites of the SASZ and third interface may be indicating the depth of some mafic units. 


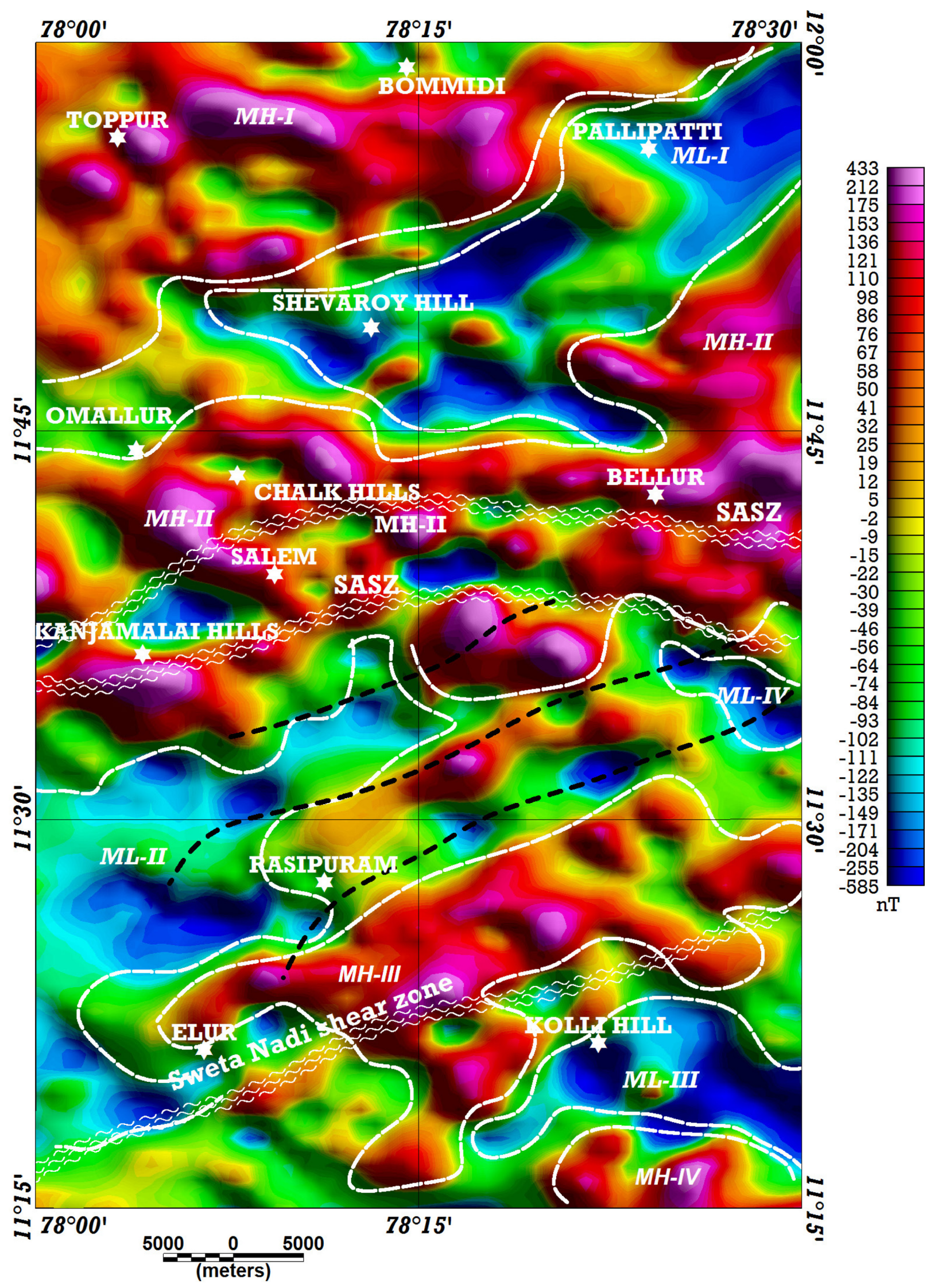

Figure 6. Reduced to Equator (RTE) magnetic anomaly map. MH-I to MH-III are magnetic high; ML-I to ML-III are magnetic low; white lines are tentative boundaries of different zones. The SASZ is marked after Behera et al. (2019). The black dotted lines indicate fault also marked after Behera et al. (2019). 


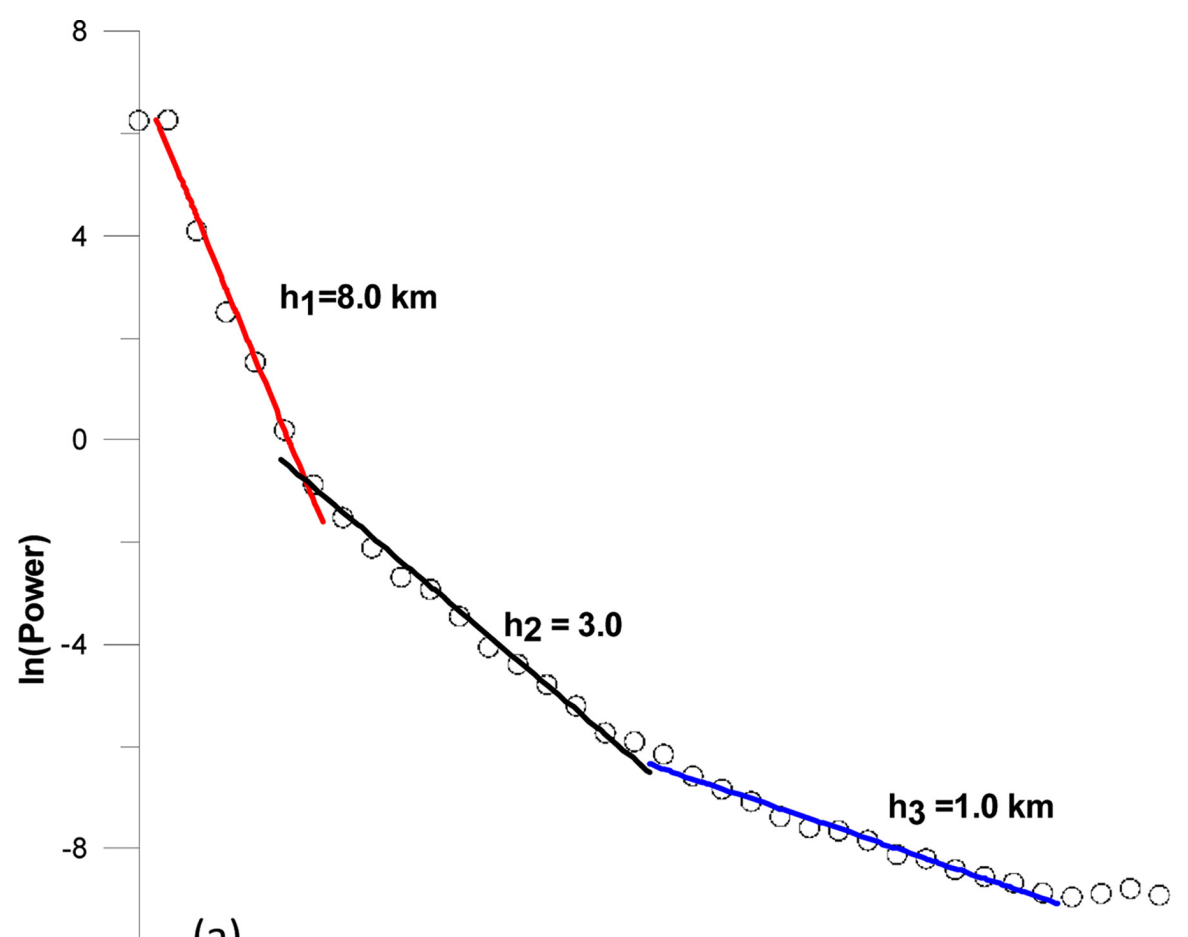

(a)
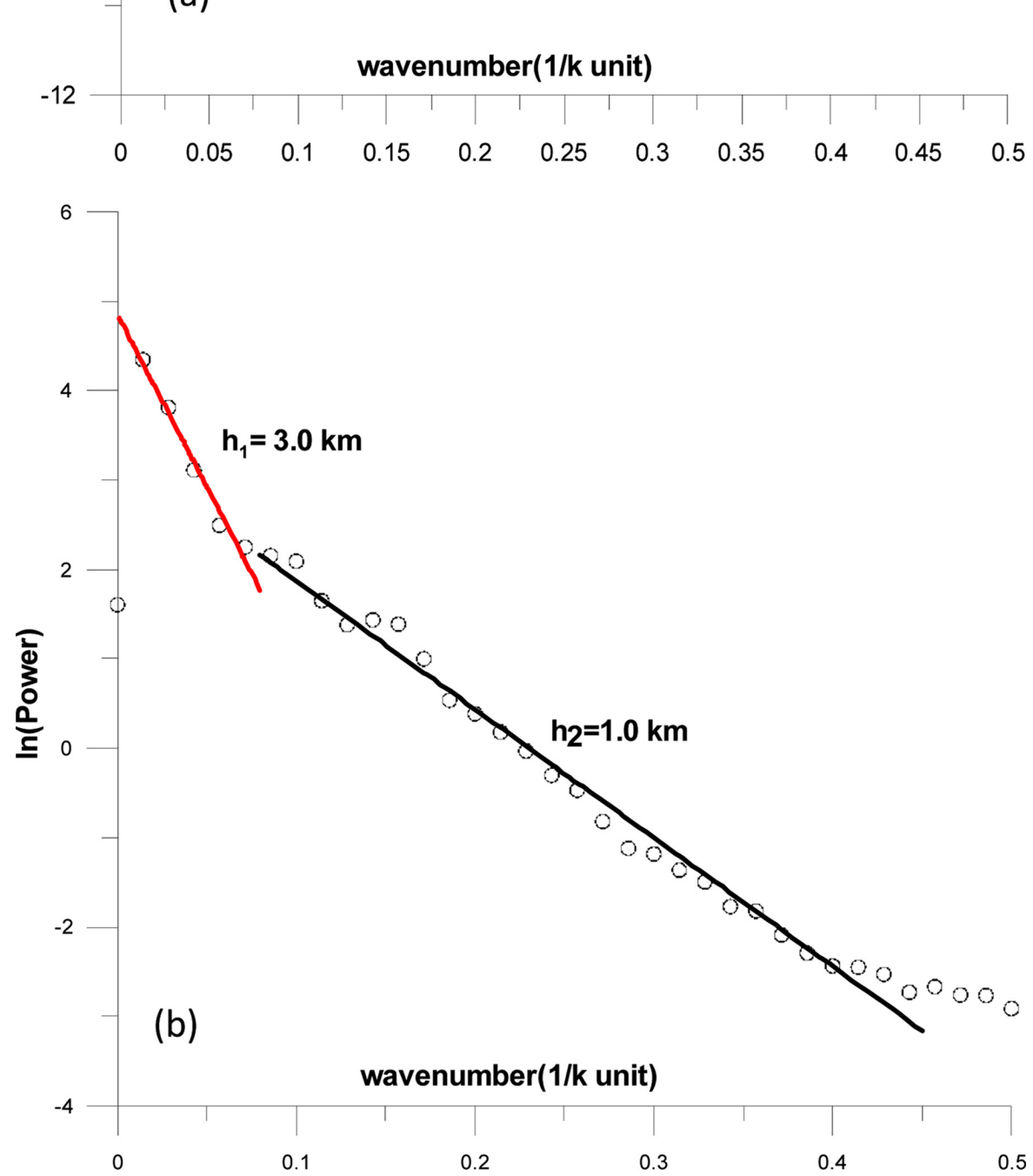

Figure 7. Radially averaged power spectrum of (a) gravity data and (b) magnetic data. $h_{1}, h_{2}$ are depth to the density/magnetic interfaces. See text for details. 


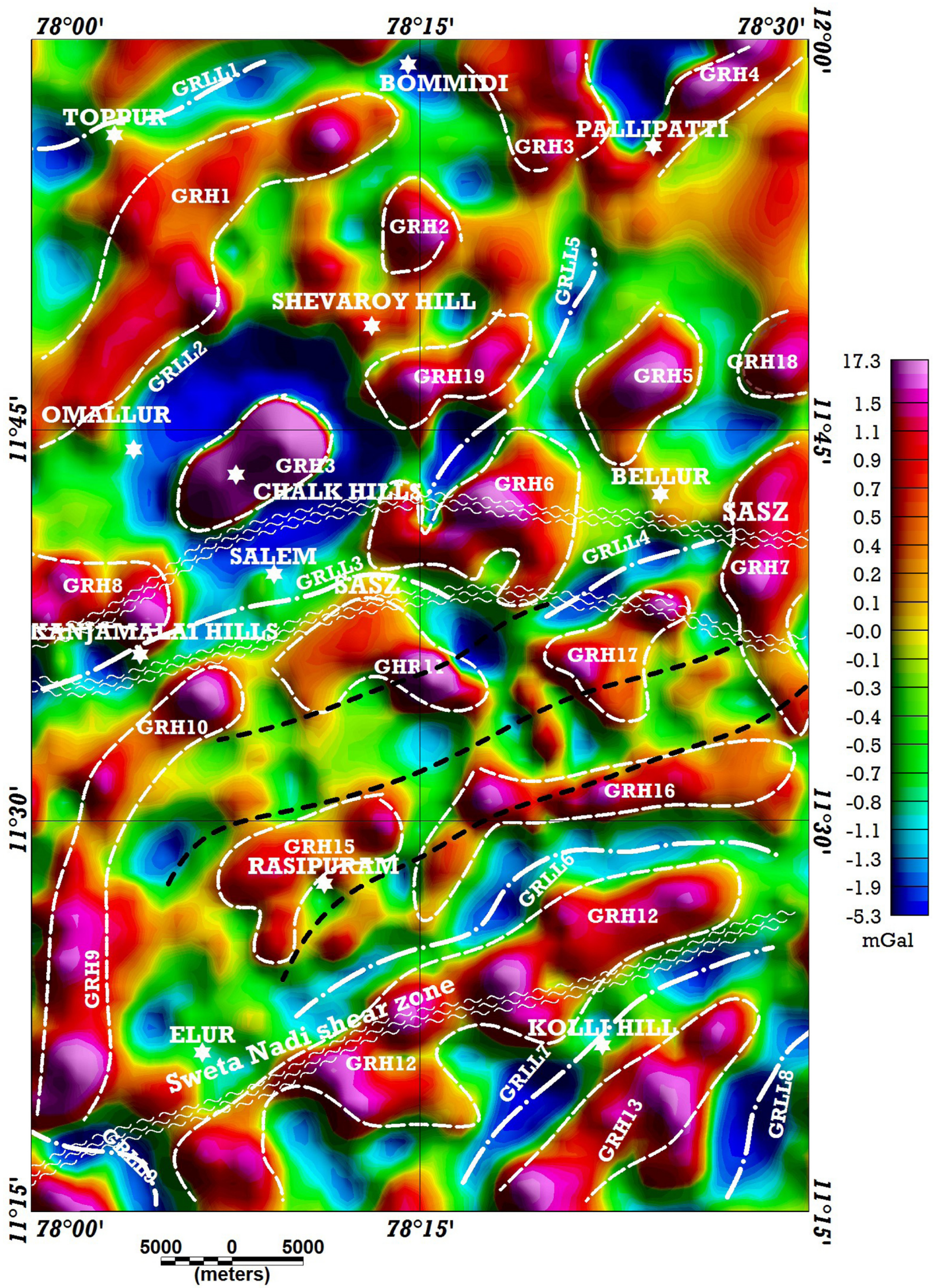

Figure 8. Residual gravity map. GRH-1 to GRH-19 indicate residual gravity high zones; GRLL1 to GRLL9 indicate gravity residual low linear interpreted as minor shear. The Salem-Attur Shear Zone (SASZ), Sweta-Nadi shear zone and faults (black dashed line) are modified from Behera et al. (2019). 
The power spectrum of magnetic delineates two linear slopes (Fig. 7b) that indicate the depths of magnetic interfaces at $3.0 \mathrm{~km}$ and $1.0 \mathrm{~km}$. The first interface may be indicating average depth extension of KMC and the second interface may be stating the depth to some local mafic rock units.

\section{Residual Gravity Anomaly}

The boundaries of residual gravity highs and the axis of the linear gravity lows are marked in Fig. 8 with the dashed line. Most of the anomalies are not apparent on the Bouguer gravity map (Fig. 5). We have interpreted linear gravity lows as the shear, and many of them show good corroboration with the geological marked shear zones. The circular residual gravity low (GRLL2) anomaly may represent an occurrence of low-density granitoids surrounding the Chalk hill. The linear anomalies GRLL3, GRLL4 running through Kanjamalai hill and south of Bellur follows the geological trend of SASZ. At southeastern part, near Kolli hill, the eastern flank of GRLL7, GRLL8, and GRLL9 are in good corroboration with the geologically marked shear zone. The other shear brought out from the residual gravity map includes GRLL1 and GRLL9.

The circular residual gravity closure (GRH3, Fig. 8) is also well represented in the Bouguer gravity map (GCH1, Fig. 5). It indicates the deeper causative source of the anomaly. The other high(s) marked as GRH1, GRH2 etc., probably represent high-density mafic units which cannot be directly correlated with the exposed geology as in many cases mafic bands are concealed. The GRH8 anomaly zone reflects the highdensity mafic unit of Kanjamalai hill, which indicates very shallow depth extension of the mafic units. The anomaly GRH9 may indicate the presence of an assemblage of high-density lithounits like pyroxenite/meta gabbro under the exposed anorthosite (Fig. 4). It is interesting to notice that GRH9 and GRH10 occur along the north-south trend, which may indicate the extension of the SAC. Another residual gravity high band in NE-SW direction encompassing GRH12 is a conspicuous feature of the residual gravity anomaly map. The trend well corroborates with the geologically marked Sweta-Nadi shear Zone. It may indicate disposition of high-density lithounit along the shear zone. A very thin band of banded magnetite quartzite and pyroxene granulite are exposed with NW-SE trend (Fig. 2), in the area enclosed by GRH16. It indicates the occurrence of pyroxene granulite or BMQ within the area encircled by GMH16. The GRH13 is a prominent residual gravity high band in the south of Kolli hill, which indicates the occurrence of high-density rock unit as the majority of the rock samples pertinent to GRH13 shows density values $2.8 \mathrm{gm} / \mathrm{cc}$ or more (Fig. 4).

\section{Regional Gravity Anomaly}

The regional gravity maps (Fig. 9) depicts enhance response from the sources below $2.5 \mathrm{~km}, 5 \mathrm{~km}, 7.5 \mathrm{~km}$, and $10 \mathrm{~km}$, respectively. Fig 9(a) represent $5 \mathrm{~km}$ upward gravity map where signatures of NEESWW trending gravity low are present but subdued in the surface map (Fig. 5). The map shows (Fig. 9) that the circular gravity high (GUP5, GUP-10, Fig. 9a \& b) at Chalk hill dies out at $15 \mathrm{~km}$ upward continued map (GUP-15). It indicates that the ultramafic unit is hosting magnesite deposit of limited depth extension which extends maximum up to the $\sim 7.5 \mathrm{~km}$. The SASZ represented by linear gravity low is also not traceable at GUP-15. It suggests SASZ does not continue up to mid-crustal depth. The gravity high at the southeastern part and gravity low at the north-western part of the study area is easily traceable up to $20 \mathrm{~km}$ upward continued map (GUP-20), which suggests the continuation of the anomaly sources up to mid-crustal depth. Further, GUP-15 and GUP-20 suggest the systematic variation of upper crustal density along NW-SE direction; where NW part is represented by the low-density acidic rock in the middle to lower crust, and SE part is represented by the high-density mafic rock in the upper to lower crust. The part of the anomalies (both low and high) may also be attributed to the variation of crustal thickness as it appears from the GUP-20 that at the southeast part crust is thinner compared to the north-west part. The regional trend of the anomalies is in a NE-SW direction. The moderate gradient of isogals in the central part of the GUP-15 and GUP-20 may indicate that the contact is faulted or thrusted.

\section{Horizontal Derivative of Gravity Data}

The horizontal derivative of gravity data has been computed by using Geosoft software and map is presented in Fig. 10. The most striking feature of the map is the linear gravity gradient observed in ENE-WSW and NNE-SSW directions. The trend in the eastern part of the study area follows the trend of the SASZ, but from the central part, it swings towards the north-west. It indicates that there is abrupt lithological discontinuity along the area marked by the white dashed line in Fig. 10. It incorporates mafic/ultramafic hill like Kanjamalai hill and Chalk hill.

\section{Euler Deconvolution}

For the present study, we seek to estimate the edges of the spherical type of source at Chalk hill, which is causing high gravity closure. The solutions derived from gravity data are presented in Fig. 11(a). The solutions indicate that ultramafic units comprising Chalk hill is a sphere-like structure with the edge of the source ranges from $4-8 \mathrm{~km}$.

From magnetic data, we obtained a good cluster of solutions for structural index (SI) ' 3 ', which designates spherical geometry (Fig. 11b). The tightest clusters of solutions were found to be associated with the $\mathrm{KMC}$. It suggests that the KMC is a magnetically spherical structure with depth to the edge of the source varies from 2.5 to $5 \mathrm{~km}$. The other solution sets are observed at the northeast of Shevaroy hill, north of Bellur, south of Kolli hill, and in few other places. This solution sets suggest the occurrence of the magnetically anomalous sphere-like structure.

\section{Analysis of Gravity and Magnetic Signatures Along a Profile}

Profiles A-A' is selected in the NNW-SSE direction, which cuts across the geological units to analyze the gravity and magnetic anomaly responses over different lithounit along the profile AA' (marked in Fig. 2 and 5). The Fig. 12 depicts the variation of gravity, residual gravity, regional gravity and magnetic anomalies along the profile.

The gravity anomaly in profile A-A' shows a total variation from $-100 \mathrm{mGal}$ to $-43 \mathrm{mGal}$. Two distinct feature observed in the profile, a gravity high (GH1) at Chalk hill and a gravity high gradient (GHG1) at the southeast part of the profile. Wavelength and amplitude of the 

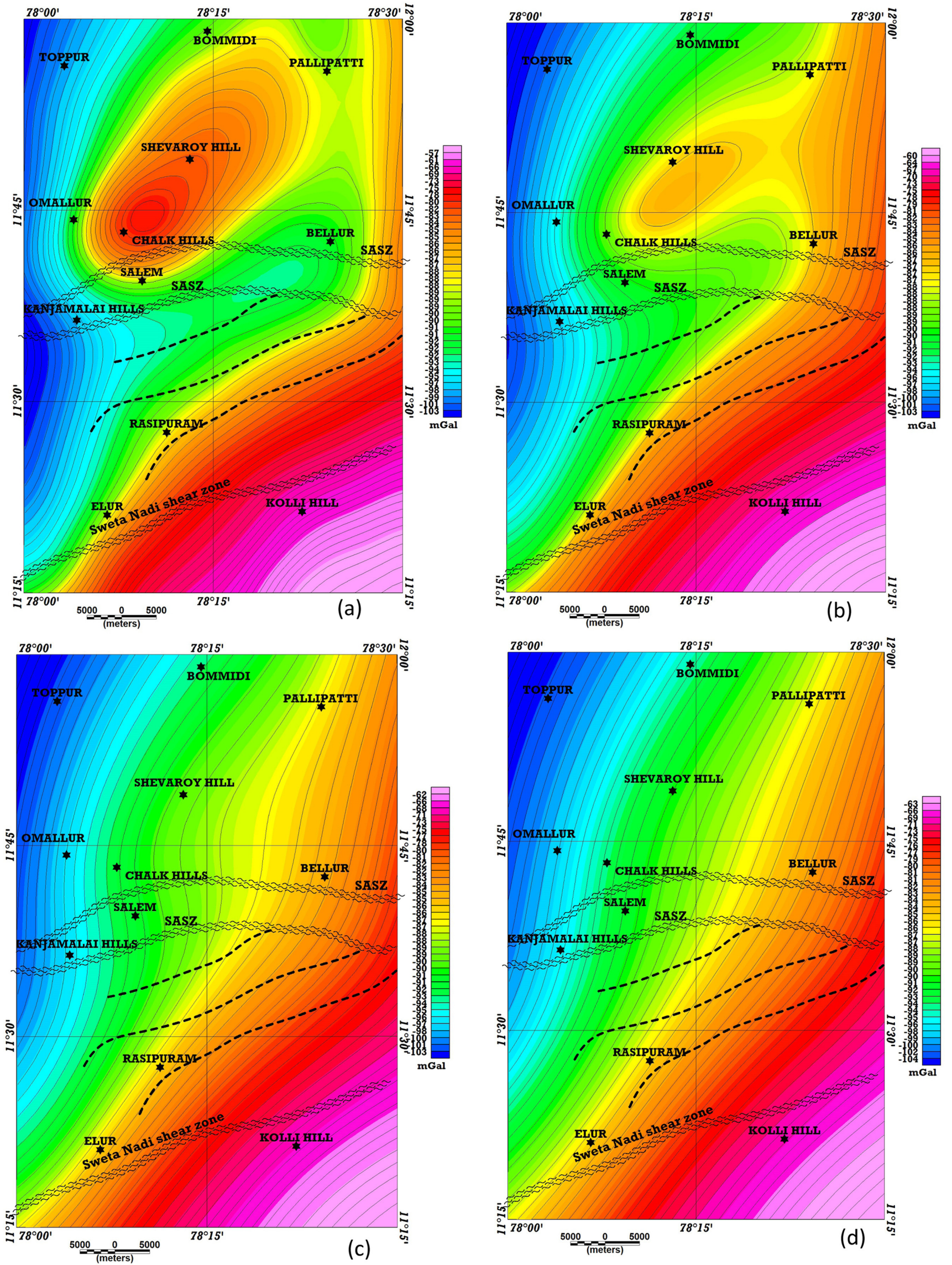

Figure 9. Regional gravity map. Gravity map upward continued (a) to $5 \mathrm{~km}$ (GUP-5), (b) to $10 \mathrm{~km}$ (GUP-10), (c) to $15 \mathrm{~km}$ (GUP-15), (d) to 20 km (GUP-20). 


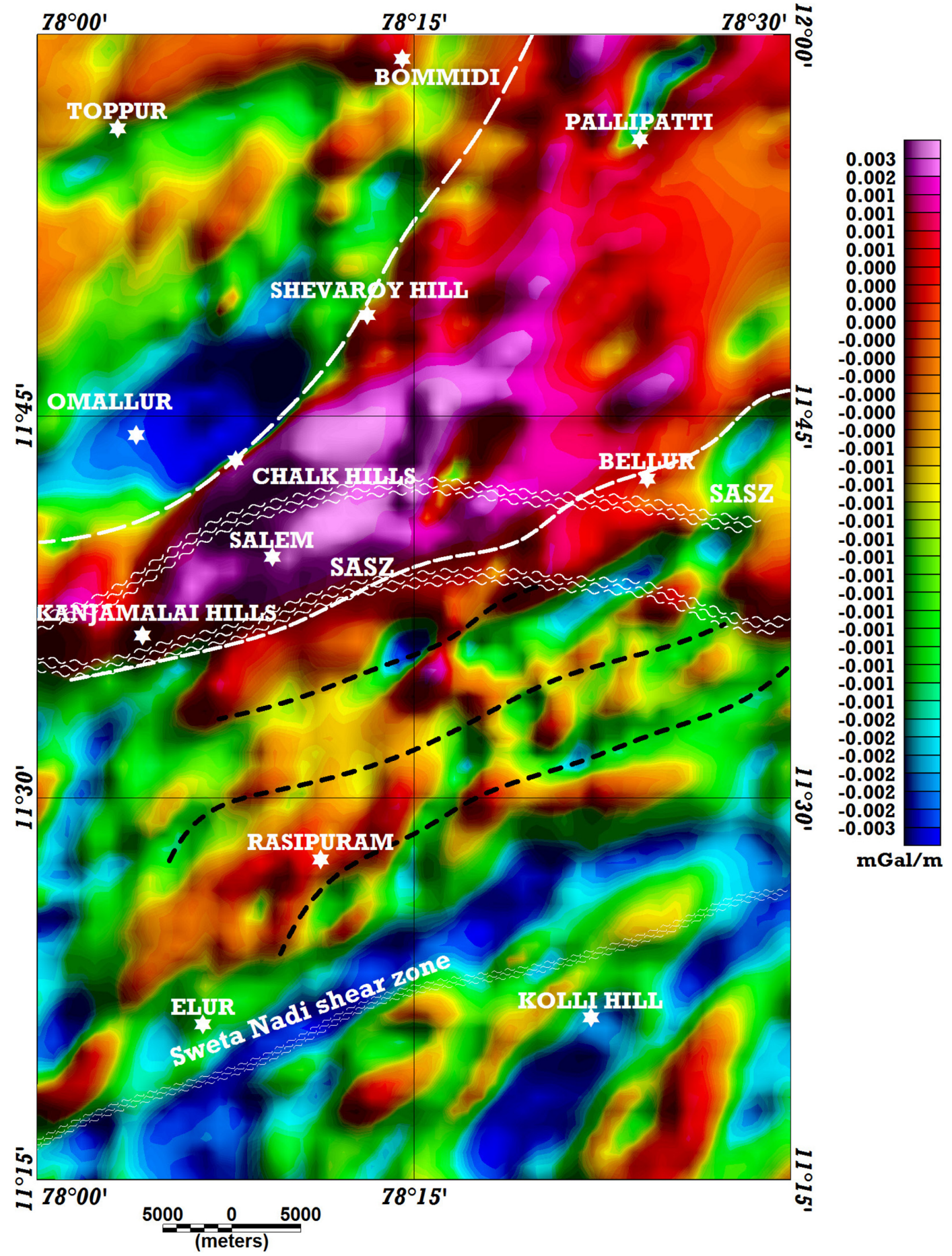

Figure 10. Horizontal gradient of gravity data. White line encircles the maxima. See the ENE-WSW to NNE-SSW trending gravity maxima.

anomaly GH1 suggest the occurrence of the high-density body at the surface and of limited depth extension. GHG1 suggests contact between the comparatively low-density crustal unit and the high-density crustal unit, which may be associated with a fault. It also suggests that crust may be tilted towards NW. The high-frequency components in the gravity profile are amplified in the residual gravity profile. Residual gravity profile shows high over Chalk hill, which reconfirms the fact that maximum component of $\mathrm{GH} 1$ is contributed from the shallow source. At SE part of the profile, a residual gravity high is observed. It indicates the occurrence of the high-density unit at this place. Upward continuation to $15 \mathrm{~km}$ is considered as regional gravity profile as it is devoid of any high or moderate frequency component. The profile shows moderate gradient $\left(\mathrm{m}_{1}=28^{\circ}\right)$ at NW part of the profile, high gradient $\left(\mathrm{m}_{2}=37^{\circ}\right)$ at the southeast part of the profile and very gentle gradient at the central part of the profile, with gravity value ranging from $-104 \mathrm{mGal}$ to $-63 \mathrm{mGal}$. The steeper gradient in southeastern part suggests a change in upper-crustal lithology and the causative source of Bouguer gravity high at SE part is deeper. The seismic study shows crustal thick- 

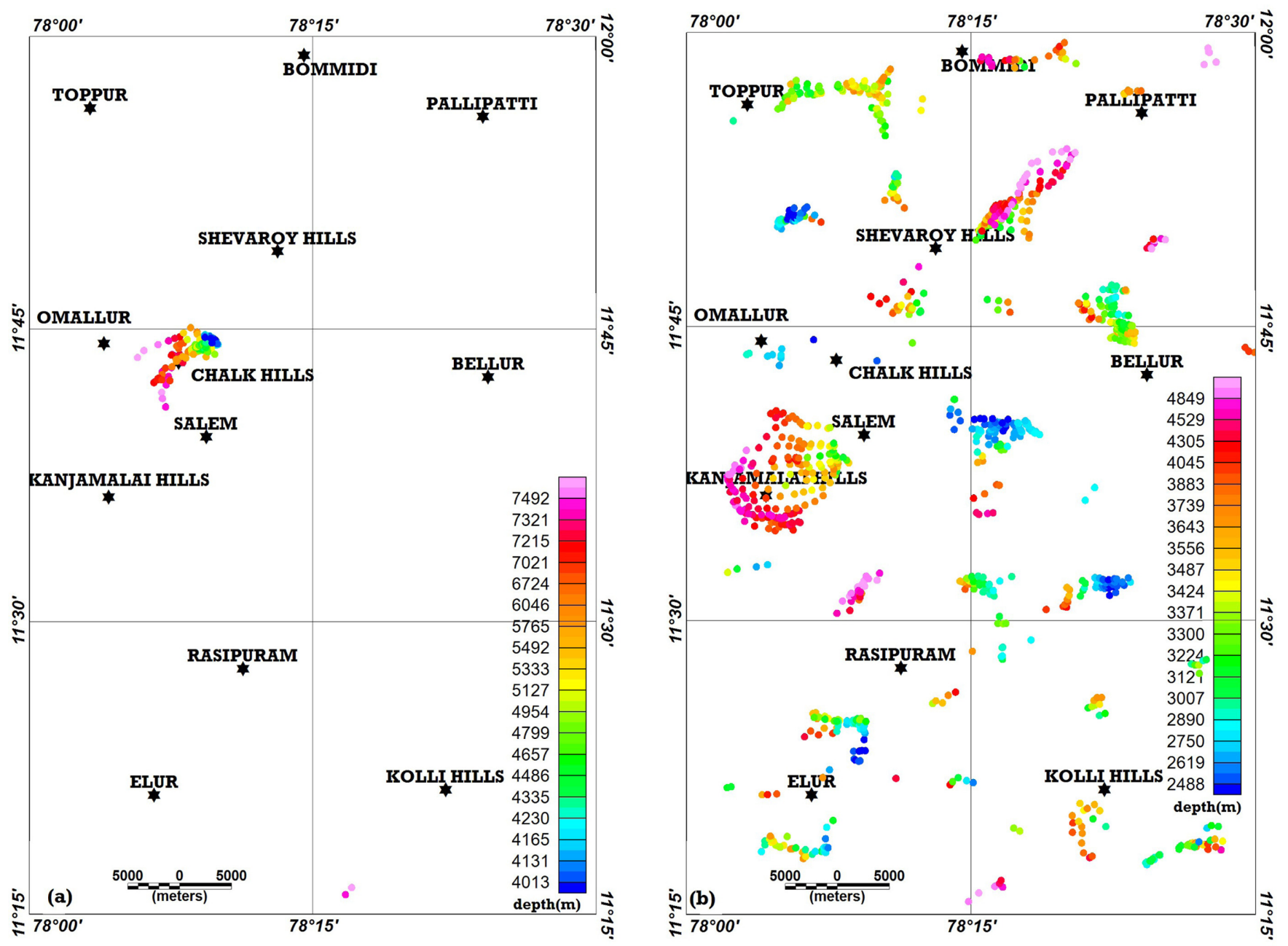

Figure 11. Euler solution from (a) gravity data with Structural Index (SI) 2, window size (WS) 10, depth of tolerance(DT) $5 \%$; and from (b) magnetic data, with SI 3, WS 10, DT 8\%.

ness in the northern part of the study area near Bommidi is $\sim 41-42 \mathrm{~km}$ (Reddy, 2003). The Moho depth variation across the area inferred from the isostatic study is $36 \mathrm{~km}$ to $40 \mathrm{~km}$ with relatively thicker crust in the northern part of the area (Kumar et al., 2011). Upward continuation to $15 \mathrm{~km}$ (Fig. 10) was used for estimating crustal thickness using the formula $\mathrm{T}=31.6-.078 \Delta \mathrm{g}$. (Qureshy, 1967; Radhakrishna, 2003). It shows that crustal thickness varies from $40 \mathrm{~km}$ to $36 \mathrm{~km}$ from NW to SE, which may be due to thrusting of the SW part over the NW part. The magnetic profiles show high over gneiss and low over mafic rock units. However, GH1 is not associated with any definite magnetic signature.

\section{Gravity-Magnetic Joint Modelling}

The gravity-magnetic joint model (Fig. 13) shows that the ultramafic unit hosting magnesite deposit at Chalk hill has depth extension of $\sim 7.5 \mathrm{~km}$ with a density (D) of $3130 \mathrm{~kg} \cdot \mathrm{m}^{-3}$ and susceptibility (S) value - $0.0141 \mathrm{SI}$ unit. Here, it is to inform that depth extension of the gravity anomaly GH1 is mainly constrained from the results of Euler Solutions (Fig. 11(a)). The initial density value is assigned from the measured density value of dunite $(3.07 \mathrm{gm} / \mathrm{cc})$.

At southeastern part, the model brought out the unexposed contact of two crustal units with different density and susceptibility. The upper crust up to Kolli hill (block-13) with D value of $2762.7 \mathrm{~kg} \cdot \mathrm{m}^{-3}$ and S value of 0.0009 SI unit, probably represents silicic moderate-density rock units. While the crustal unit, towards the SE part of the profile starting from Kolli hill (block-12) probably represents basic high-density rock unit (D: $2801.8 \mathrm{~kg} \cdot \mathrm{m}^{-3} \mathrm{~S}: 0.0039 \mathrm{SI}$ unit). A high-density rock (block-10) at SSE part of the profile represents a mafic unit, probably meta gabbro. The low-density unit (block-6) at the eastern part of GH1 probably represents mylonites, and it extends up to $\sim 4 \mathrm{~km}$ depth. This is the depth extension of the SASZ, which have an average width of $18 \mathrm{~km}$. Some mafic rock unit with density $2870.0 \mathrm{~kg} \cdot \mathrm{m}^{-3}$ intrudes the SASZ. At the western part of the profile, the low-density unit (2671.4 $\mathrm{kg} \cdot \mathrm{m}^{-3}$ ) probably designates granites or sheared gneiss.

\section{Discussions}

\section{Gravity-Magnetic Signatures of the SASZ and Blocks Across it}

The present study area is placed in a significant tectonic environment between two crustal blocks, Shevaroy Block (SB) at north, and 


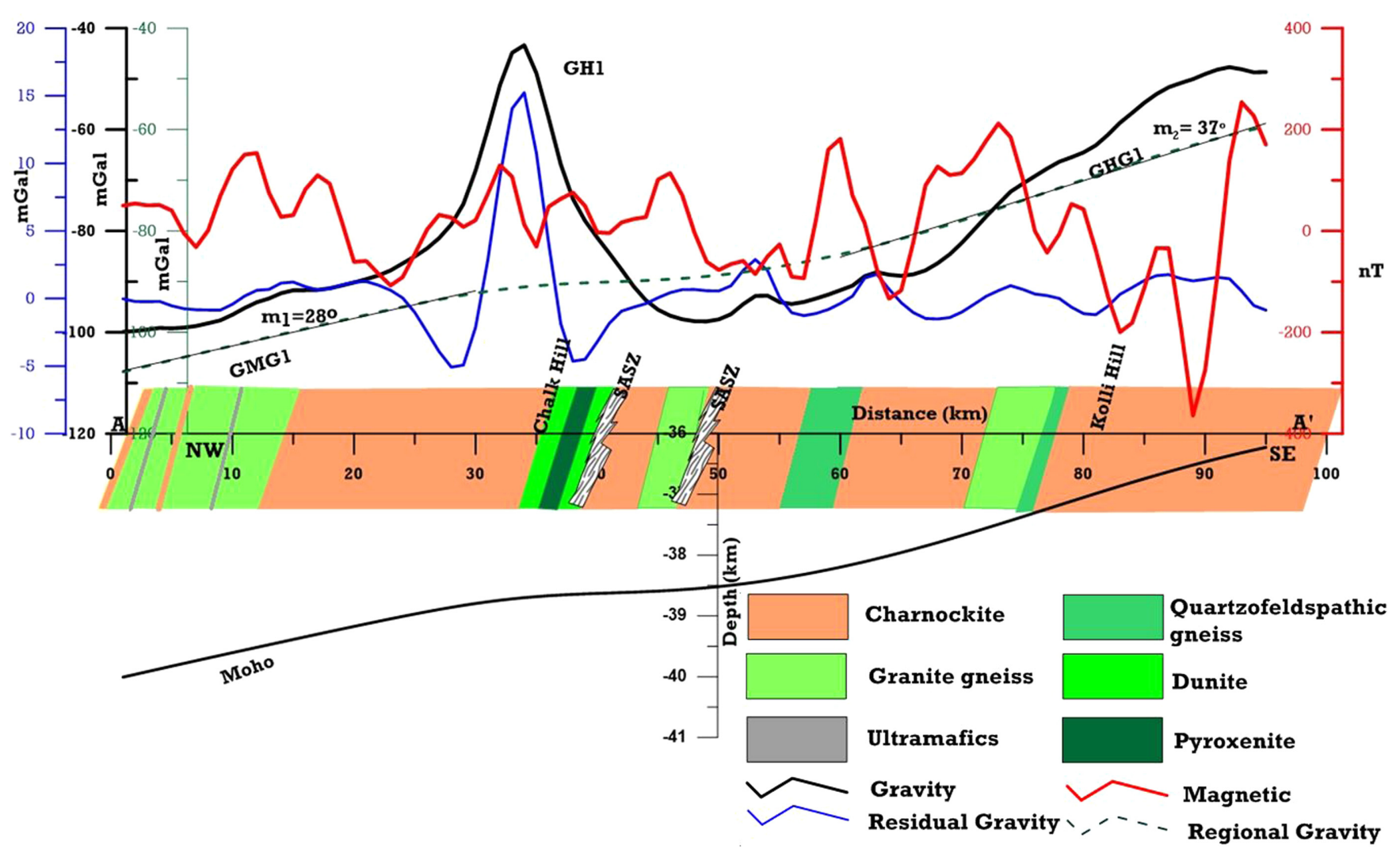

Figure 12. Gravity and magnetic responses over different geological lithounits along the profile $A A^{\prime}, m_{1}, m_{2-}$ slope; GH1- Gravity high; GMG1Gravity moderate gradient; GHG1-Gravity high gradient. Moho depth calculated using the relation T=31.6-.078 $\Delta$ (Qureshy et al., 1967).

Namakkal Block (NkB) at the south, which is divided by the SASZ. The gravity map shows that the SASZ represents a distinct anomaly pattern. The shear zone is narrow parallel, planar, sub-parallel domain, where strain is concentrated relative to their surrounding regions (Ramsay, 1980). The SASZ, an imbricate thrust with varying dips, preserves a dextral sense of movement, but individual domain exhibits variation in the sense of movement from the bulk sense and strain progression towards central part (Chetty, 1996; Bhadra, 2000; Kumar and Prasannakumar, 2009, Behera et al., 2019). Our study shows that the SASZ is reflected in gravity map (Fig. 5) as a moderately low zone (GLL1) with elongated isogals trending in ENE-WSW direction. The low linear anomalies delineated from residual gravity map are predominantly trending in NE-SW directions (Fig. 8). The magnetic map shows magnetic highs along the shear zone with pockets of magnetic lows. However, NNE part of the shear zone is represented by magnetic low (ML-I). It indicates that the SASZ is predominantly composed of nonmagnetic rock units with mafic intrusive up to Bellur. The isogals pattern of the GLL1 (Fig. 5) indicates that the northern part of the SASZ starting from Bellur is less sheared and characterized by mafic rocks. The maximum vertical extension of the shear zone as revealed by gravity modelling is $\sim 4 \mathrm{~km}$. It seems that the evolution of the SASZ is a manifestation of thin-skin tectonism.

The geological study by Behera et al. (2019), suggests that the Shevaroy and Namakkal blocks share similar lithologies and common magmatic deformational histories as charnockite magmatism took place between ca 3.2-2.6 Ga. The blocks were contiguous before the SalemAttur shear zone affected them at ca. 2.0 Ga and the Namakkal block over-thrusted on to the Salem block in N-NNE direction. Clark et al. (2009) estimated the weighted mean age (zircon, U-Ph-Pb, isotopic data) of two charnockitie samples from (50 km north of Salem, Fig. 2) Shevaroy Block as $\sim 2482-2473 \mathrm{Ma}$. The charnockite samples from Kolli hill (in NkB; Fig. 2) indicate that the age ( $\mathrm{Sm}-\mathrm{Nd}$ isotopic analysis) of the samples varies from 2.6-3.2 Ga (Tomson et al., 2013). These two studies indicate that charnockite massif from Shevaroy and Nammakal block may have different magmatic history. The different pressuretemperature condition was reported at Shevaroy hill and Kolli hill (Raith et al., 1983) for the charnockite massifs. For Shevaroy hill, temperature-pressure was $680^{\circ} \mathrm{C}$ and $7.5 \mathrm{~kb}$, while for Kolli hill, it was $680{ }^{\circ} \mathrm{C}$ and $8.4 \mathrm{~kb}$. It suggests that mafic rocks of Kolli hill are of deeper crustal origin.

The geochronological studies (Clark et al., 2009; Mohan et al., 2013; Santosh et al., 2012, 2013) suggest that the southern margin of the DC had witnessed subduction and arc accretion regime twice but widely separated in time. The northern part of the PCSS including NGB forms Neoarchean-early Paleoproterozoic subduction-accretion belt (Santosh et al., 2012); where multiple subduction systems had pulled the oceanic arcs toward the large continent with progressive closure of ocean basin (Santosh et al., 2013). The continental growth through late Archean arc magmatism in a convergent margin setting, is also suggested (Samuel at al. 2014) in the Nilgiri Block (NB). The tectonic model proposed by Santosh et al. (2013) also suggests that the rheologically weak southern margin of the DC underwent trans-crustal rifting due to extensional tectonics during Neoproterozoic partly in consequence of slab-pull force generated by down going oceanic lithosphere. 


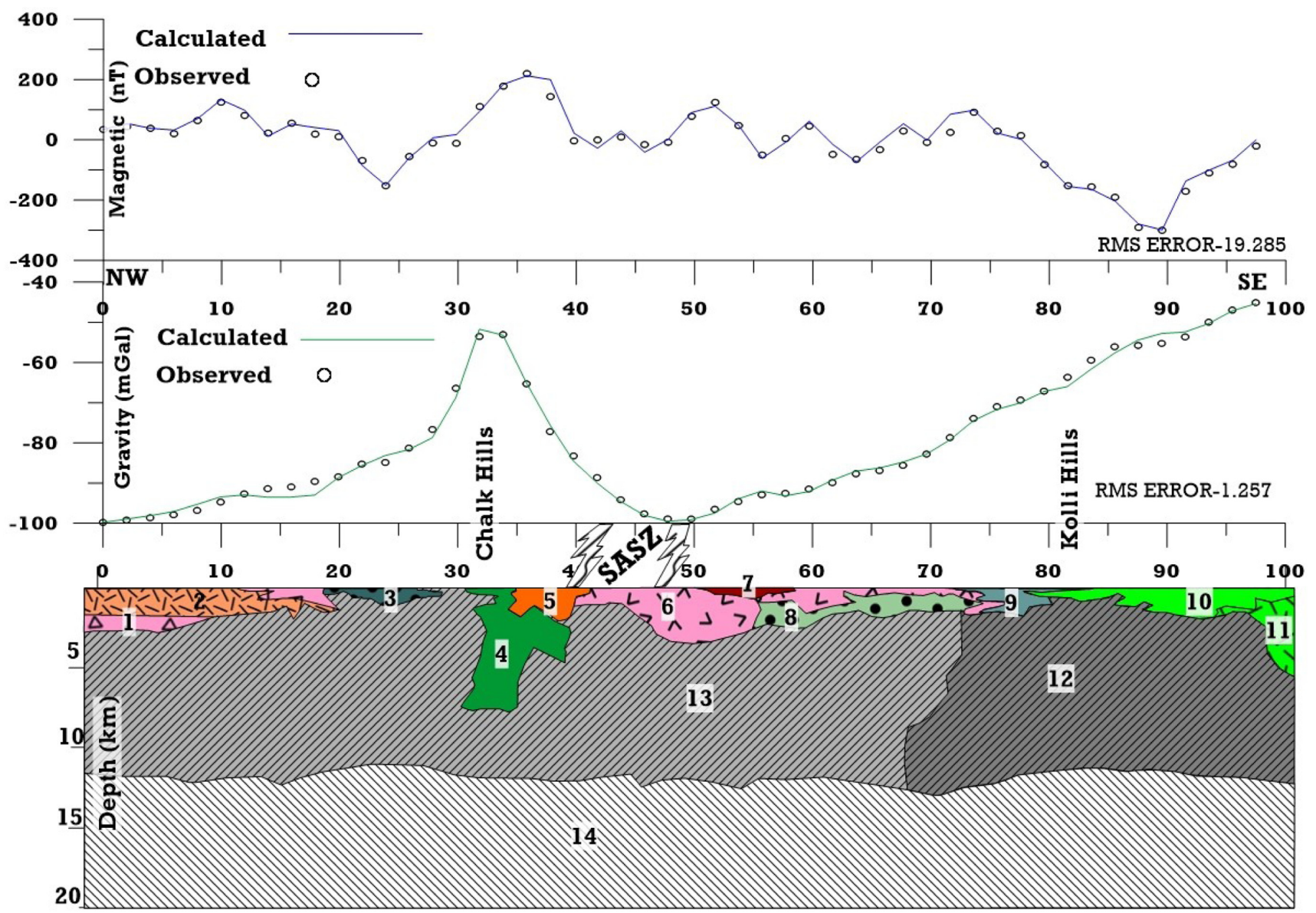

\begin{tabular}{|c|c|c|c|c|c|c|c|c|c|c|c|c|c|c|}
\hline Block No & 1 & 2 & 3 & 4 & 5 & 6 & 7 & 8 & 9 & 10 & 11 & 12 & 13 & 14 \\
\hline $\begin{array}{c}\text { Density } \\
\left(\mathrm{kg} . \mathrm{m}^{-3}\right)\end{array}$ & 2671.0 & 2763.0 & 2683.0 & 3130.00 & 2720.0 & 2668.70 & 2729.50 & 2834.70 & 2890.0 & 3095.80 & 2952.50 & 2801.80 & 2762.70 & 2889.0 \\
\hline $\begin{array}{c}\text { Susceptibility } \\
\text { in SI unit }\end{array}$ & 0.0001 & -0.035 & 0.0306 & -0.0141 & -0.030 & -0.0016 & -0.0388 & 0.0298 & 0.008 & 0.0908 & -0.0007 & 0.0039 & 0.0009 & 0.0053 \\
\hline
\end{tabular}

Figure. 13 Gravity-magnetic joint model along the profile AA'. Density and susceptibility values of the blocks are provided in the chart.

In the present study, gravity map shows that northern and the southern blocks of the SASZ are represented by two distinct anomaly domains (Fig. 5). Regional gravity map reveals that the north-western part of the gravity map is indicative of a dominant low and it is attributed to thick Dharwar crust. The map (Fig. 5) shows that the southeastern part of the area is represented by gravity high with isogals trending in the NESW direction. The gravity-magnetic modelling shows that comparatively denser mafic upper-crust is attributing for this high at the southern block of the SASZ. It indicates that a high density mafic crustal unit might have accreted to the southern margin of the SASZ through arc magmatism. The MT profile passing through the vicinity of the southeastern part of the study area (Fig. 1) shows a conductive upper crustal unit. The high-density crustal blocks, associated with high pressure, along the ancient active margins signify the up-thrusted high-grade metamorphic terranes accreted through continental collision (Fountain and Salisbury, 1981; Thomas, 1992). The gravity signatures (Fig. 5) at the southeastern part of the SASZ indicates that the rock unit of the Kolli hill probably represents high-density granulite body or continental fragment extending up to the mid-crustal depth. The isogals pattern indicates that the continent fragment (we refer it as Kolli Block) at the south of the SASZ was probably thrusted onto the Shevaroy Block. The analysis of the present study along with geochronological data suggest Shevaroy Block and Kolli Blocks are two different crustal fragments. The high-density mafic lithounits at the south eastern part (GRH12 \& GRH13, Fig. 8) as observed from the residual gravity anomaly map may represent the slivers of oceanic realm. This inference may open up a debate regarding the possibility of considering the PCSS as an amalgamation of continental fragments.

The horizontal gravity map (Fig. 10) shows a strong gravity maxima in NE-SW direction encompassing the KMC and the Chalk hill. This may represent the geophysical signature of part of the trans-crustal rift zone as proposed by Santosh et al. (2014). The circular gravity high (GCHI, Fig. 5) representing the mafic-ultramafic complex (Chalk hill) near Salem is a prominent feature of the study area. It represents a high-density nonmagnetic unit and confined within the top $\sim 8 \mathrm{~km}$ of the upper crust. In a recent study by Yellappa et al. (2019), suggests that the complex was formed during Neoproterozoic, which can be correlated with Alaskan-type complex. The Alaskan-type complexes are generally 
uplifted fragments of the deep levels of island arcs formed as small intrusions in convergent plate margin settings. The gravity-magnetic joint modelling suggests that the emplacement of the mechanism was a forceful diapiric ascent that may be due to asthenospheric upwelling followed by rifting.

At northern part as discussed earlier, KMC is represented by moderate residual gravity high and a magnetic low. It indicates that KMC is predominantly magnetic inhomogeneity with very shallow crustal root or base of the KMC is formed by granites. Noack (2013) suggested that protoliths of KMC are derived from the Archean mafic-oceanic crust and ocean floor sediments. The model furnished by the author further proposed that KMC represent an accretionary wedge formed during Neoarchean-Paleoproterozoic subduction-accretion processes along the southern margin of the DC. The present study shows that the gravity-magnetic signature of the KMC does not have a spatial extension, so the tectonic significance of KMC is not well manifested in the present study.

\section{Accretion of Terranes}

In the SGT, numerous distinct crustal micro-blocks have been delineated (SGT, Ratheesh-Kumar et al., 2016). The micro-blocks were gathered along the multiple zones of ocean closure during Archean to Paleoproterozoic (Li et al., 2018). Study in the southeastern margin of Dharwar Craton indicates that two micro-blocks Shevaroy and Madras welded together along Nallamalai Suture Zone (NLSZ, Li et al., 2018, Fig. 1). The study suggests an eastward oceanic subduction and ocean closure along the NLSZ that welds the Shevaroy and Madras Blocks. The present research indicates the presence of distinct micro-blocks in terms of gravity-magnetic and conductivity (from MT study) in the southern part of the SASZ. We propose an amalgamation of a microblock (Kolli Block) along the southern margin of SASZ, but its mechanism of the assembly to SGT needs further study.

The inference from the paleomagnetic study indicated that the Dharwar Craton (DC) and the SGT or Shevaroy Block forms a single crustal domain with high-grade rocks of SGT represent the deeper section of the DC (Dash et al., 2013). The present study shows a linear Horizontal Gradient maxima (Fig. 10), which implicates density inhomogeneity along NE-SW direction. It further suggests that this is an essential tectonic boundary separating the DC and SGT, which negates the proposition that the SGT is contiguous with the Dharwar Craton.

\section{Conclusions}

The comprehensive study using gravity and magnetic methods across the Salem-Attur Shear Zone (SASZ) delivers the following significant findings or valuable insights regarding shallow and deeper crustal architecture across the SASZ. The conclusions also provide substantial clues for deriving an evolutionary model of the Southern Granulite Terrane (SGT).

- An orderly increase of Bouguer gravity values is observed from NW to SE direction. The joint modelling of gravity-magnetic data reveals significant differences in upper crustal density and magnetization in the northern and southern part of SASZ. Crustal unit represented by Kolli hill may have accreted along the southern margin of Dharwar Craton (DC). The SASZ has a shallow vertical extension $(\sim 4 \mathrm{~km})$ and is characterized by diamagnetic rock.

- The ultramafic complex of Chalk hill appears as spherical plug type body with depth extension of $\sim 7-8 \mathrm{~km}$.

\section{Acknowledgements}

Authors are sincerely thankful to Prof. Dr. Jin-Yong Lee, Editor-inChief, EPISODES, Journal of International Geoscience, and the anonymous reviewer for the thorough review and valuable suggestions for improvement of the manuscript. Authors place sincere thanks to Director General, Geological Survey of India, kind permission to publish the work. The authors are also thankful to the Director, IIT (ISM), Dhanbad and Head, Dept. of App. Geophysics, IIT (ISM), Dhanbad for their keen interest in this study. Views and opinions expressed in this article are those of the authors and do not necessarily reflect the views/ opinions of the organization they belong to. The paper is generated from FSP item no.2015-16/NGPM/SR/AP/2015/066. SKP is thankful to ISRO, Dept. of Space, Govt. of India, project no. ISRO/RES/ 630/2016-17; to Science and Engineering Research Board, DST, India, project no. SB/S4/ES-640/2012 and FST/ES-I/2017/12 for their funding.

The author (s) declares that there is no conflict of interest.

\section{References}

Bauer, K., Trumbull, R.B., and Vietor, T., 2003, Geophysical images and a crustal model of intrusive structures beneath the Messum ring complex, Namibia. Earth and Planetary Science Letters, v. 216, pp. 65-80.

Behera, B.M., Waele, B.D., Thirukumaran, V., Sundaralingam, K., Narayanan, S., Sivalingam, B., and Biswal, T.K., 2019, Kinematics, strain pattern and geochronology of the Salem-Attur shear zone: Tectonic implications for the multiple sheared Salem-Namakkal blocks of the Southern Granulite terrane, India. Precambrian Research, v. 324, pp. 32-61.

Bhadra, B.K., 2000, Ductile shearing in Attur shear zone and its relation with Moyar shear zone, South India. Gondwana Research, v. 3, pp. 361-369.

Biswal, T.K., Thirukumaran, V., Ratre, K., Bandyapadhaya, K., Sundaralingam, K., and Mondal, A.K., 2010, A study of mylonites from parts of the Salem-Attur shear zone (Tamil Nadu) and its tectonic implications. Journal of the Geological Society of India, v. 75, pp. 128-136.

Blakely, R.J., 1996, Potential theory in gravity and magnetic applications. Cambridge university press.

Brandt, S., Raith, M.M., Schenk, V., Sengupta, P., Srikantappa, C., and Gerdes, A., 2014, Crustal evolution of the Southern Granulite Terrane, south India: New geochronological and geochemical data for felsic orthogneisses and granites. Precambrian Research, v. 246, pp. 91-122.

Chetty, T.R.K., 1996, Proterozoic shear zones in southern granulite terrain, India. The Archaean and Proterozoic Terrains in Southern India within East Gondwana, v. 3, pp. 77-89.

Chetty, T.R.K., and Rao, Y.B., 2006, The Cauvery shear zone, Southern Granulite Terrain, India: a crustal-scale flower structure. Gondwana Research, v. 10, pp. 77-85.

Chetty, T.R.K., Rao, Y.B., and Narayana, B.L., 2003, A structural cross section along Krishnagiri-Palani corridor, Southern Granulite terrain of India. Memoirs-Geological Society of India, pp. 255-278.

Chetty, T.R.K., Yellappa, T., and Santosh, M., 2016, Crustal architecture and tectonic evolution of the Cauvery Suture Zone, southern India. Journal of Asian Earth Sciences, v. 130, pp. 166-191. 
Choudhary, A.K., Jain, A.K., Singh, S., Manickavasagam, R., and Chandra, K., 2011, Crustal Accretion and Metamorphism of Mesoarchean Granulites in Palghat-Cauvery Shear Zone, Southern India. Journal of the Geological Society of India, v. 77, pp. 227.

Chouhan, A.K., Choudhury P., and Pal, S.K., 2020b, New evidence for a thin crust and magmatic underplating beneath the Cambay rift basin, Western India through modelling of EIGEN-6C4 gravity data. Journal of Earth System Science, 129 64, doi:10.1007/s12040-019-1335-y

Chouhan, A.K., Singh, D., Pal, S.K., and Choudhury, P., 2020a, Delineation of subsurface geological fractures in the Cambay rift and surrounding regions of NW India: an integrated approach using satellite derived EIGEN-6C4 gravity data. Geocarto International. doi:10.1080/ 10106049.2020.1716395

Christensen, N.I., Mooney, W.D., 1995, Seismic velocity structure and composition of the continental crust: A global view. Journal of Geophysical Research: Solid Earth, v. 100, pp. 9761-9788.

Clark, C., Collins, A.S., Timms, N.E., Kinny, P.D., Chetty, T.R.K., Santosh, M., 2009, SHRIMP U-Pb age constraints on magmatism and high-grade metamorphism in the Salem Block, southern India. Gondwana Research, v. 16, pp. 27-36.

Dash, J.K., Pradhan, S.K., Bhutani, R., Balakrishnan, S., Chandrasekaran, G., and Basavaiah, N., 2013, Paleomagnetism of ca. 2.3 Ga mafic dyke swarms in the northeastern Southern Granulite Terrain, India: Constraints on the position and extent of Dharwar craton in the Paleoproterozoic. Precambrian Research, v. 228, pp. 164-176.

de Castro, D.L., 2011, Gravity and magnetic joint modeling of the Potiguar Rift Basin (NE Brazil): Basement control during Neocomian extension and deformation. Journal of South American Earth Sciences, v. 31, pp. 186-198.

de Castro, D.L., Fuck, R.A., Phillips, J.D., Vidotti, R.M., Bezerra, F.H., and Dantas, E.L. 2014, Crustal structure beneath the Paleozoic Parnaíba Basin revealed by airborne gravity and magnetic data, Brazil. Tectonophysics, v. 614, pp. 128-145.

Dobrin, M.B., and Savit, C.H., 1988, Introduction to Geophysical Prospecting. (4th Edn.) McGraw-Hill, New York, 710p.

Drury, S.A., and Holt, R.W., 1980, The tectonic framework of the South Indian craton: a reconnaissance involving LANDSAT imagery. Tectonophysics, v. 65, pp. 1-15.

Drury, S.A., Harris, N.B.W., Holt, R.W., Reeves-Smith, G.J., and Wightman, R.T., 1984, Precambrian tectonics and crustal evolution in South India. The Journal of Geology, v. 92, pp. 3-20.

Fountain, D.M., and Salisbury, M.H., 1981, Exposed cross-sections through the continental crust: implications for crustal structure, petrology, and evolution. Earth and Planetary Science Letters, v. 56, pp. 263-277.

Ganguli, S.S., Pal, S.K., Rao, J.R., and Raj, B.S., 2020a, Gravity-magnetic appraisal at the interface of Cuddapah Basin and Nellore Schist Belt (NSB) for shallow crustal architecture and tectonic settings. Journal of Earth System Science, v. 129, pp. 1-17.

Ganguli, S.S., Pal, S.K., Singh, S.L., Rama Rao, J.V., and Balakrishna B., 2020b, Insights into crustal architecture and tectonics across Palghat Cauvery Shear Zone, India from combined analysis of gravity and magnetic data. Geological Journal v. 55, pp. 1-19. doi:10.1002/gj.4041

Ganguli, S.S., Singh, S., Das, N., Maurya, D., Pal, S.K., and Rao, J.V., 2019, Gravity and Magnetic Survey in Southwestern Part of Cuddapah Basin, India and its Implication for Shallow Crustal Architecture and Mineralization. Journal of the Geological Society of India, v. 93, pp. 419-430.

Gessner, K., Gallardo, L.A., Wedin, F., and Sener, K., 2016, Crustal structure of the northern Menderes Massif, western Turkey, imaged by joint gravity and magnetic inversion. International Journal of Earth Sciences, v. 105, pp. 2133-2148.

Ghosh, J.G., de Wit, M.J., and Zartman, R.E., 2004, Age and tectonic evolution of Neoproterozoic ductile shear zones in the Southern Granulite Terrain of India, with implications for Gondwana studies. Tectonics, v. 23. doi:10.1029/2002TC001444

Gibb, R.A., and Thomas, M.D., 1976, Gravity signature of fossil plate boundaries in the Canadian Shield. Nature, v. 262, pp. 199.

Gibb, R.A., Thomas, M.D., Lapointe, P.L., and Mukhopadhyay, M., 1983, Geophysics of proposed Proterozoic sutures in Canada. Precambrian Research, v. 19, pp. 349-384.

Glorie, S., De Grave, J., Singh, T., Payne, J.L. and Collins, A.S., 2014, Crustal root of the Eastern Dharwar Craton: zircon $\mathrm{U}-\mathrm{Pb}$ age and $\mathrm{Lu}-$ Hf isotopic evolution of the East Salem Block, southeast India. Precambrian Research, v. 249, pp. 229-246.

GM-SYS, 2004, Gravity/Magnetic Modeling Software: User's Guide Version 4.9. NGA Inc., 101 p.

Grady, J.C., 1971, Deep main faults in South India. Journal of Geological Society of India, v. 12, pp. 56-62.

GSI, 1995, Geological Quadrangle Map of 58/I, Geological Survey of India Publication, Kolkata, India.

GSI, 1998, Geological Map of India on 1:2,000,000 scale, Geological Survey of India Publication, Kolkata, India.

He, X.F., Santosh, M., Zhang, Z.M., Tsunogae, T., Chetty, T.R.K., Mohan, M.R., and Anbazhagan, S., 2015, Shonkinites from Salem, southern India: Implications for Cryogenian alkaline magmatism in rift-related setting. Journal of Asian Earth Sciences, v. 113, pp. 812-825.

Hearst, R.B., and Morris, W.A. 2001, Regional gravity setting of the Sudbury Structure. Geophysics, v. 66, pp. 1680-1690.

Horo, D., Pal, S.K., Singh, S., and Saurabh, 2020, Combined self-potential, electrical resistivity tomography and induced polarisation for mapping of gold prospective zones over a part of Babaikundi-Birgaon Axis, North Singhbhum Mobile Belt, India. Exploration Geophysics, v. 51, pp. 507-522. doi:10.1080/08123985.2020.1722026

Jacobsen, B.H., 1987, A case for upward continuation as a standard separation filter for potential-field maps. Geophysics, v. 52, pp. 1138-1148.

Kumar, N., Singh, A. P., and Singh, B., 2009, Structural fabric of the Southern Indian shield as defined by gravity trends. Journal of Asian Earth Sciences, v. 34, pp. 577-585.

Kumar, N., Singh, A.P., and Singh, B., 2011, Insights into the crustal structure and geodynamic evolution of the Southern Granulite Terrain of India from isostatic considerations. Pure and Applied Geophysics, v. 168, pp. 1781-1798.

Kumar, N., Singh, A.P., and Tiwari, V.M., 2020a, Gravity Anomalies, Isostasy and Density Structure of the Indian Continental Lithosphere. Episodes Journal of International Geoscience, v. 43, pp. 609-621.

Kumar, R.S., and Prasannakumar, V., 2009, Fabric evolution in SalemAttur Shear Zone, South India, and its implications on the kinematics. Gondwana Research, v. 16, pp. 37-44.

Kumar, S., Pal, S.K., Guha, A., Sahoo, S.D., and Mukherjee, A., 2020b, New insights on Kimberlite emplacement around the Bundelkhand Craton using integrated satellite-based remote sensing, gravity, and magnetic data. Geocarto International, doi:10.1080/10106049.2020. 1756459

Kumar, U., Narayan S., and Pal, S.K., 2020c, Structural and tectonic interpretation of EGM2008 gravity data around the Laccadive ridge in the Western Indian Ocean: An implication to continental crust. Geocarto International, doi:10.1080/10106049.2020.1856193

Kumar, U., Pal, S.K., Sahoo, S.D., Narayan, S., Saurav, Mondal, S., Gunguli, S.S., 2018, Lineament mapping over Sir Creek offshore and its surroundings using high resolution EGM2008 Gravity data: An integrated derivative approach. Journal of. Geological. Society of India, v. 91, pp. 671-678.

Kumar U., Narayan S., and Pal, S. K., 2019, New insights on structure and tectonics over the Laxmi Ridge using EIGEN6C4 modelled gravity data, Indian Journal of Geo Marine Sciences, v. 48, pp. 1999-2005.

Li, S.S., Santosh, M., Ganguly, S., Thanooja, P.V., Sajeev, K., Pahari, A., and Manikyamba, C., 2018, Neoarchean microblock amalgamation in southern India: Evidence from the Nallamalai Suture Zone. Precambrian Research, v. 314, pp. 1-27.

Marquardt, D.W., 1963, An algorithm for least-squares estimation of nonlinear parameters. Journal of the society for Industrial and Applied 
Mathematics, v. 11, pp. 431-441.

Mishra, D.C., 2011, Gravity and magnetic methods for geological studies: Principles, Integrated Exploration and Plate Tectonics. Hyderabad: BS Publications, $958 \mathrm{p}$.

Mishra, D.C., and Kumar, V.V., 2005, Evidence for Proterozoic collision from airborne magnetic and gravity studies in Southern Granulite Terrain, India and signatures of recent tectonic activity in the Palghat Gap. Gondwana Research, v. 8, pp. 43-54.

Mohan, M.R., Satyanarayanan, M., Santosh, M., Sylvester, P.J., Tubrett, M., and Lam, R., 2013, Neoarchean suprasubduction zone arc magmatism in southern India: Geochemistry, zircon U-Pb geochronology and Hf isotopes of the Sittampundi Anorthosite Complex. Gondwana Research, v. 23, pp. 539-557.

Mohanty, D.P., and Chetty, T.R.K., 2014, Possible detachment zone in Precambrian rocks of Kanjamalai Hills, Cauvery Suture Zone, Southern India: implications to accretionary tectonics. Journal of Asian Earth Sciences, v. 88, pp. 50-61.

Naganjaneyulu, K., and Harinarayana, T., 2003, Evidence for continentcontinent collision zone in the South Indian Shield region. Gondwana Research, v. 6, pp. 902-911.

Narayan, S., Sahoo, S.D., Pal, S.K., Kumar, U., Pathak, V.K., Majumdar, T.J., and Chouhan, A., 2017, Delineation of structural features over a part of the Bay of Bengal using total and balanced horizontal derivative techniques. Geocarto International, v. 32, pp. 1-16, doi:10.1080/ 10106049.2016.1140823

Noack, N.M., Kleinschrodt, R., Kirchenbaur, M., Fonseca, R.O., and Münker, C., 2013, Lu-Hf isotope evidence for Paleoproterozoic metamorphism and deformation of Archean oceanic crust along the Dharwar Craton margin, southern India. Precambrian Research, v. 233, pp. 206-222.

Pal, S.K., and Majumdar, T.J., 2015, Geological appraisal over the Singhbhum-Orissa Craton, India using GOCE, EIGEN6-C2 and in-situ gravity data. International Journal of Applied Earth Observations and Geoinformation, v. 35, pp. 96-119. doi:10.1016/j.jag.2014.06.007

Pal, S.K., Majumdar, T.J., Pathak, V.K., Narayan, S., Kumar, U., and Goswami, O.P., 2015, Utilization of high resolution EGM2008 gravity data for geological exploration over the Singhbhum-Orissa Craton, India. Geocarto International, v. 31, pp. 783-802. doi:10.1080/10106049.2015.1076064

Pal, S.K., Narayan, S., Majumdar T.J., and Kumar, U., 2016, Structural mapping over the 850E ridge and surroundings using EIGEN6C4 High Resolution Global Combined Gravity Field Model: an integrated approach. Marine Geophysical Research, v. 37, pp. 159-184. doi:10.1007/s11001016-9274-3

Peucat, J.J., Jayananda, M., Chardon, D., Capdevila, R., Fanning, C.M., and Paquette, J.L., 2013, The lower crust of the Dharwar Craton, Southern India: Patchwork of Archean granulitic domains. Precambrian Research, v. 227, pp. 4-28.

Pilkington, M., 2006, Joint inversion of gravity and magnetic data for twolayer models. Geophysics, v. 71, pp. 35-42.

Plavsa, D., Collins, A.S., Foden, J.D., and Clark, C., 2015, The evolution of a Gondwanan collisional orogen: A structural and geochronological appraisal from the Southern Granulite Terrane, South India. Tectonics, v. 34, pp. 820-857.

Praveen, M.N., Santosh, M., Yang, Q.Y., Zhang, Z.C., Huang, H., Singanenjam, S., and Sajinkumar, K.S., 2014, Zircon U-Pb geochronology and Hf isotope of felsic volcanics from Attappadi, southern India: implications for Neoarchean convergent margin tectonics. Gondwana Research, v. 26, pp. 907-924.

Qureshy, M.N., Aravamadhu, P.S., and Bhatia, S.C., 1967, Some regional gravity traverses through India. In Proceedings of the Symposium on Upper Mantle Project. Geophysical Research Board NGRI, pp. 122133.

Radhakrishna, M., Kurian, P.J., Nambiar, C.G., and Murty, B.V.S., 2003, Nature of the crust below the Southern Granulite Terrain (SGT) of Peninsular India across the Bavali shear zone based on analysis of gravity data. Precambrian Research, v. 124, pp. 21-40.

Radice, S., Klinger, F.L., Maffini, M.N., Pinotti, L.P., Demartis, M., Giménez, M., and Coniglio, J.E., 2018, Crustal structure in high deformation zones: Insights from gravimetric and magnetometric studies in the Guacha Corral shear zone (Eastern Sierras Pampeanas, Argentina). Journal of South American Earth Sciences, v. 82, pp. 261-273.

Raith, M.M., Srikantappa, C., Buhl, D., and Koehler, H., 1999, The Nilgiri enderbites, South India: nature and age constraints on protolith formation, high-grade metamorphism and cooling history. Precambrian Research, v. 98, pp. 129-150.

Raith, M., Raase, P., Ackermand, D., and Lal, R.K., 1983, Regional geothermobarometry in the granulite facies terrane of South India. Earth and Environmental Science Transactions of The Royal Society of Edinburgh, v. 73, pp. 221-244.

Ramadass, G., Rao, I.R., and Himabindu, D., 2006, Crustal configuration of the Dharwar craton, India, based on joint modeling of regional gravity and magnetic data. Journal of Asian Earth Sciences, v. 26, pp. 437-448.

Ramsay, J.G., 1980, Shear zone geometry: a review. Journal of structural geology, v. 2, pp. 83-99.

Rao, V.V., and Prasad, B.R., 2006, Structure and evolution of the Cauvery Shear Zone system, Southern Granulite Terrain, India: evidence from deep seismic and other geophysical studies. Gondwana Research, v. 10, pp. 29-40.

Ratheesh-Kumar, R.T., Santosh, M., Yang, Q.Y., Ishwar-Kumar, C., Chen, N.S., and Sajeev, K., 2016, Archean tectonics and crustal evolution of the Biligiri Rangan Block, southern India. Precambrian Research, v. 275, pp. 406-428.

Reddy, P.R., 2003, Deep seismic reflection and refraction/wide-angle reflection studies along Kuppam-Palani transect in the southern granulite terrain of India. Memoir of Geological society of India, v. 50, pp. 79-106.

Reid, A.B., Allsop, J.M., Granser, H., Millett, A.T., and Somerton, I.W., 1990, Magnetic interpretation in three dimensions using Euler deconvolution. Geophysics, v. 55, pp. 80-91.

Reid, A.B., and Thurston, J.B., 2014, The structural index in gravity and magnetic interpretation: Errors, uses, and abuses. Geophysics, v. 79, pp. 61-66.

Sahoo, S.D., and Pal, S.K., 2019, Mapping of structural lineaments and fracture zones around the Central Indian Ridge $\left(10^{\circ} \mathrm{S}-21^{\circ} \mathrm{S}\right)$ using EIGEN 6C4 Bouguer gravity data. Journal of Geological Society of India, v. 94, pp. 359-366.

Sahoo, S.D., and Pal, S.K., 2020, Crustal Structure and Moho topography of the southern part $\left(18^{\circ} \mathrm{S}-25^{\circ} \mathrm{S}\right)$ of central Indian ridge using highresolution EIGEN6C4 global gravity model data. Geo-Marine Letters, v. 41, pp.1-20. doi:org/10.1007/s00367-020-00679-z

Samuel, V.O., Santosh, M., Liu, S., Wang, W., and Sajeev, K., 2014, Neoarchean continental growth through arc magmatism in the Nilgiri Block, southern India. Precambrian Research, v. 245, pp. 146-173.

Santosh, M., 2020, The Southern Granulite Terrane: A synopsis. Episodes Journal of International Geoscience, v. 43, pp. 109-123.

Santosh, M., and Li, S.S., 2018, Anorthosites from an Archean continental arc in the Dharwar Craton, southern India: implications for terrane assembly and cratonization. Precambrian Research, v. 308, pp. 126-147.

Santosh, M., Maruyama, S., and Sato, K., 2009, Anatomy of a Cambrian suture in Gondwana: Pacific-type orogeny in southern India? Gondwana research, v. 16, pp. 321-341.

Santosh, M., Shaji, E., Tsunogae, T., Mohan, M.R., Satyanarayanan, M., and Horie, K., 2013, Suprasubduction zone ophiolite from Agali hill: petrology, zircon SHRIMP U-Pb geochronology, geochemistry and implications for Neoarchean plate tectonics in southern India. Precambrian Research v. 231, pp. 301-324.

Santosh, M., Xiao, W.J., Tsunogae, T., Chetty, T.R.K., and Yellappa, T., 2012, The Neoproterozoic subduction complex in southern India: SIMS zircon $\mathrm{U}-\mathrm{Pb}$ ages and implications for Gondwana assembly. Precambrian Research, v. 192, pp. 190-208.

Santosh, M., Yang, Q.Y., Shaji, E., Tsunogae, T., Mohan, M.R., and 
Satyanarayanan, M., 2015, An exotic Mesoarchean microcontinent: the Coorg Block, southern India. Gondwana Research, v. 27, pp. 165-195.

Santosh, M., Yang, Q.Y., Mohan, M.R., Tsunogae, T., Shaji, E. and Satyanarayanan, M., 2014, Cryogenian alkaline magmatism in the Southern Granulite Terrane, India: Petrology, geochemistry, zircon U$\mathrm{Pb}$ ages and $\mathrm{Lu}-\mathrm{Hf}$ isotopes. Lithos, v. 208, pp. 430-445.

Sato, K., Santosh, M., Tsunogae, T., Chetty, T.R.K., and Hirata, T., 2011, Laser ablation ICP mass spectrometry for zircon $\mathrm{U}-\mathrm{Pb}$ geochronology of metamorphosed granite from the Salem Block: Implication for Neoarchean crustal evolution in southern India. Journal of Mineralogical and Petrological Sciences, v. 106, pp. 1-12.

Singh, A.P., Kumar, N., and Singh, B., 2006, Nature of the crust along Kuppam-Palani geotransect (South India) from Gravity studies: Implications for Precambrian continental collision and delamination. Gondwana Research, v. 10, pp. 41-47.

Singh, A.P., Mishra, D.C., Gupta, S.B., and Rao, M.P., 2004, Crustal structure and domain tectonics of the Dharwar craton (India): insight from new gravity data. Journal of Asian Earth Sciences, v. 23, pp. 141-152.

Singh, B., Rao, M.P., Prajapati, S.K., and Swarnapriya, C., 2014, Combined gravity and magnetic modeling over Pavagadh and Phenaimata igneous complexes, Gujarat, India: Inference on emplacement history of Deccan volcanism. Journal of Asian Earth Sciences, v. 80, pp. 119133.

Spector, A., and Grant, F.S., 1970, Statistical models for interpreting aeromagnetic data. Geophysics, v. 35, pp. 293-302.

Talwani, M., 1964, Computation of magnetic anomalies caused by twodimensional bodies of arbitrary shape. Computers in the mineral industries, v. 1, pp. 464-480.

Talwani, M., Worzel, J.L., and Landisman, M., 1959, Rapid gravity computations for two-dimensional bodies with application to the Mendocino submarine fracture zone. Journal of geophysical research, v. 64, pp. 49-59.

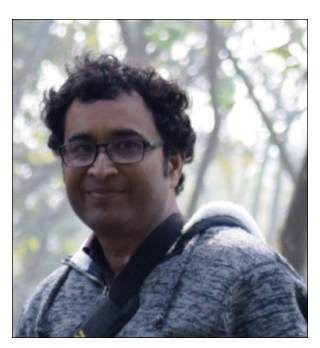

Shuva Shankha Ganguli is a professional Geophysicist for the last fifteen years. In initial five years, he was engaged in groundwater exploration and management in Central Ground Water Board, Ministry of Water Resources, Govt of India. Since 2010 , he is actively engaged in ground gravity-magnetic studies in different parts on South Indian Shield (SIS) as Geophysicist in Geological Survey of India. His major research interests are to study the crustal architecture and tectonics in Southern Granulite Terrane (SGT), India. He has published several research articles in international journals and conferences.

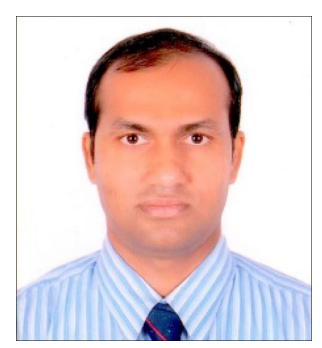

Sanjit Kumar Pal is an Associate Professor at Department of Applied Geophysics, IIT (Indian School of Mines), Dhanbad; obtained M.Sc. Tech. in Geophysics from Banaras Hindu University and PhD from IIT Kharagpur. Initially, he has worked as a Geophysicist in NHPC. He has executed 7 R\&D projects and 22 consultancy projects. He has guided $5 \mathrm{PhD}$, and a couple of $\mathrm{PhD}$ students are working in different fields of earth sciences. He has authored in more than 50 research papers, 20 international conferences, 40 national conferences. His research interests include crustal structure analysis, mineral Exploration, mining geophysics, environmental-hazard assessment and archaeological geophysics.
Telford, W.M., Telford, W.M., Geldart, L.P., Sheriff, R.E., and Sheriff, R.E., 2001, Applied geophysics, Cambridge university press.

Thakurta, J., 2018, Alaskan-Type Complexes and Their Associations With Economic Mineral Deposits. In Processes and Ore Deposits of Ultramafic-Mafic Magmas through Space and Time. Elsevier, pp. 269-302.

Thomas, M.D., 1992, Ancient collisional continental margins in the Canadian shield: geophysical signatures and derived crustal transects. Springer, Dordrecht, In Basement Tectonics, v. 8, pp. 5-25.

Tiwari, V.M., Rao, M.V., Mishra, D.C., and Singh, B., 2006, Crustal structure across Sikkim, NE Himalaya from new gravity and magnetic data. Earth and Planetary Science Letters, v. 247, pp. 61-69.

Tomson, J.K., Rao, Y.B., Kumar, T.V., and Choudhary, A.K., 2013, Geochemistry and neodymium model ages of Precambrian charnockites, Southern Granulite Terrain, India: Constraints on terrain assembly. Precambrian Research, v. 227, pp. 295-315.

Vaish J., and Pal S.K., 2015, Geological mapping of Jharia Coalfield, India using GRACE EGM2008 gravity data: a vertical derivative approach. Geocarto International, v. 30, pp. 388-401. doi:10.1080/10106049.2014. 905637

Webring, M., 1985, SAKI; a Fortran program for generalized linear inversion of gravity andmagnetic profiles. US Geological Survey, pp. 85-122.

Williams, H.A., Cassidy, J., Locke, C.A., Spörli, K.B., 2006, Delineation of a large ultramafic massif embedded within a major SW Pacific suture using gravity methods. Tectonophysics, v. 424, pp. 119-133.

Yellappa, T., Santosh, M., and Manju, S., 2019, The mafic-ultramafic complex of Salem, southern India: An analogue for Neoproterozoic Alaskantype complex. Geological Journal, v. 54, pp. 3017-3040.

Yellappa, T., Venkatasivappa, V., Koizumi, T., Chetty, T.R.K., Santosh, M. and Tsunogae, T., 2014, The mafic-ultramafic complex of Aniyapuram, Cauvery Suture Zone, southern India: Petrological and geochemical constraints for Neoarchean suprasubduction zone tectonics. Journal of Asian Earth Sciences, v. 95, pp. 81-98.

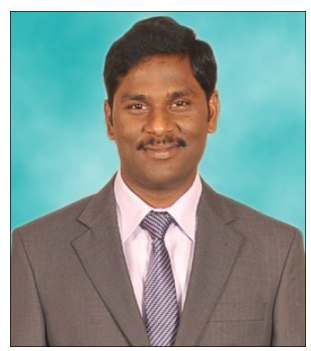

Sundaralingam $\boldsymbol{K}$. is a petrologist and structural geologist; obtained $\mathrm{PhD}$ from Indian Institute of Technology, Bombay; started initial career focusing on the geophysical study to understand the characters of rocks in the Southern Granulite Terrane and Dharwar Craton of Southern India. He now is focused on geologic mapping and studying the Precambrian rocks of Dharwar Craton, Southern India. He is presently working as Senior Geologist in Geological Survey of India, since 2012. He received Senior Research Fellowship award from CSIR for the year 2011-12 and published several research articles in national and international peer-reviewed journals and conferences.

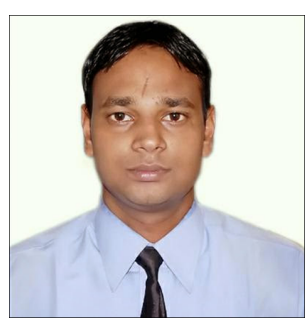

Pankaj Kumar is working as a Geophysicist in Geological Survey of India for last five years. He has been actively engaged in ground gravity \& magnetic survey for mapping and mineral exploration in different parts of South Indian Shield (SIS). He also has three year working experience in CSIR, CIMFR, Dhanbad, India as Project assistant for mine planning, coal petrology and coal logging. 